\title{
Larval recruitment in a region of strong, persistent upwelling and recruitment limitation
}

\author{
Steven G. Morgan ${ }^{1,2, *}$, Jennifer L. Fisher ${ }^{1}$, Amber J. Mace ${ }^{1,3}$ \\ ${ }^{1}$ Bodega Marine Laboratory, University of California Davis, 2099 Westside Drive, PO Box 247, Bodega Bay, \\ California 94923-0247, USA \\ ${ }^{2}$ Department of Environmental Science and Policy, University of California Davis, 1 Shields Avenue, Davis, \\ California 93510, USA
}

${ }^{3}$ Present address: California Ocean Science Trust, 1330 Broadway, Suite 1135, Oakland, California 94612-2530, USA

\begin{abstract}
Larvae are thought to be highly vulnerable to offshore transport of upwelling regions, limiting recruitment to infrequent wind relaxation and downwelling events. However, larvae could also be transported onshore by upwelled bottom waters, onshore wind-forcing or internal tides throughout the water column. We determined the relative importance of these hypothetical mechanisms for the timing of recruitment of 8 invertebrate taxa during the peak upwelling season in a region of strong, persistent upwelling. Recruitment was determined for $5 \mathrm{yr}$ at an open embayment near the surface and bottom of the water column to examine the interaction of behavioral and physical processes regulating larval recruitment. Postlarvae consistently recruited near the surface or near the bottom depending on the species. Onshore delivery of larvae during wind relaxations and reversals did not best explain recruitment patterns in our area for most taxa. Only mussels consistently recruited more during these events, and they recruited in bottom rather than surface waters. Six crab taxa recruited primarily during upwelling. Recruitment of 7 taxa was intermittently correlated with the maximum tidal range, suggesting that internal waves also may deliver larvae onshore. Thus larvae may recruit by multiple processes in upwelling regions rather than being limited to infrequent relaxation events, leaving the mechanisms responsible for observed spatial patterns in larval recruitment and adult densities unexplained. Comprehensive studies of the behavioral and physical processes underlying larval recruitment and post-settlement mortality are needed to explain observed temporal and spatial variation in population dynamics and community structure in upwelling regions.
\end{abstract}

KEY WORDS: Larval recruitment · Recruitment limitation · Larval transport · Upwelling · Population dynamics · Community structure

Resale or republication not permitted without written consent of the publisher

\section{INTRODUCTION}

Larval recruitment, the process of onshore delivery of larvae to suitable settlement sites, is a key determinant of the dynamics and structure of populations and communities; however, it is highly variable in space and time due to the effect of changing ocean conditions on larval production, survival and transport (Morgan 1995, 2001, Underwood \& Keough 2001). Identifying the biophysical mechanisms that govern larval transport is essential for understanding how variation in ocean conditions affects recruitment to adult habitats. Larval transport often is determined by the vertical distributions of larvae in vertically stratified currrents, where larvae near the surface are carried in the opposite direction of larvae at depth (Epifanio \& Garvine 2001, Queiroga \& Blanton 2004). This enables larvae to remain nearby or migrate various distances from natal populations (Swearer et al. 2002, Morgan 2006, Becker et al. 2007). How larvae 
reach suitable adult habitats depends on the depth preferences of larvae relative to currents and other physical processes operating at different depths (Kingsford et al. 2002, Sponaugle et al. 2002). Determining the multiple processes returning larvae to adult populations is especially important in recruitmentlimited regions where larval supply more strongly influences the distribution and abundance of adults than density-dependent regions where settlement and post-settlement mortality are high (Victor 1983, Connell 1985, Gaines \& Roughgarden 1985, Doherty \& Fowler 1994, Connolly et al. 2001).

Recruitment limitation is believed to be widespread in regions of strong upwelling along the western margins of continents (Roughgarden et al. 1988, Shkedy \& Roughgarden 1997, Connolly \& Roughgarden 1998, Menge et al. 2004). Strong equatorward winds combined with the Coriolis force transport surface waters toward the equator and offshore (Ekman transport), while cold, nutrient-rich bottom waters upwell along the shore generating high productivity (Hickey 1998). Larvae in surface waters may be advected far from shore by strong upwelling (Parrish et al. 1981, Yoshioka 1982, Gaines \& Roughgarden 1985, Roughgarden et al. 1988) and accumulate along an upwelling front that forms between cold upwelled water and warmer water offshore (Roughgarden et al. 1988, 1992). This front moves shoreward as upwelling winds relax, delivering larvae in water masses that are warmer and lower in salinity at the surface compared to the cold and more saline waters found throughout the water column during upwelling (Table 1). Thus episodic recruitment may be limited to brief wind relaxation events and years of weaker upwelling (Yoshioka 1982, Gaines \& Roughgarden 1985, Roughgarden et al. 1988, Farrell et al. 1991). Upwelling strength varies with latitude, yielding abundant recruitment, intense post-settlement interactions and high mortality in regions of weaker upwelling, while limited recruitment, weaker post-settlement interactions and low mortality occur in regions of strong upwelling (Roughgarden et al. 1988, Broitman et al. 2001, Connolly et al. 2001, Menge et al. 2004).
Recruits can be delivered alongshore as well as onshore when prevailing winds relax. Eddies form in the lee of headlands concentrating larvae in high abundances during upwelling and generating recruitment hotspots along otherwise recruitment-limited shores (Graham et al. 1992, Wing et al. 1995, 1998, Graham \& Largier 1997, Lagos et al. 2005, Mace \& Morgan 2006a). Larvae of species that occur in the upper water column are transported poleward from these larval accumulation areas in a buoyant, alongshore boundary current during relaxation events, thereby replenishing populations (Wing et al. 1995, 1998, 2003, Lundquist et al. 2000). For example, in the lee of the Point Reyes headland in northern California, USA, estuarine water from San Francisco Bay flows poleward along the coast taking several days to travel $90 \mathrm{~km}$ to the north (Table 1; Send et al. 1987, Wing et al. 1995). Larvae are transported poleward mostly during years with distinct relaxation events (Lundquist et al. 2000, Wing et al. 2003).

Wind forcing may deliver larvae to adult habitat nearshore during times other than brief relaxation events. Larvae can be transported onshore during downwelling when winds reverse direction (Shanks \& Brink 2005, Queiroga et al. 2006). They also could recruit onshore over short distances in downwind drifts of cold, saline surface waters in the daytime via the sea breeze (Shanks 1995, Jacinto \& Cruz 2008) or via Stokes drift in large shoaling waves that are refracted toward shore (Table 1). Further, larvae that occur deep in the water column could be delivered onshore in cold, saline water in bottom currents generated by upwelling (Table 1; Grantham 1997, Mace \& Morgan 2006a, Shanks \& Brink 2005). Recruitment limitation would not be expected to occur if larvae recruited during upwelling conditions.

The timing of onshore recruitment also can be determined by tidal forcing and the timing of the spring transition, which is a seasonal shift in atmospheric forcing that drives ocean currents along the west coast of the USA. Large, tidally generated internal waves and bores can transport larvae onshore along the

Table 1. Proposed mechanisms of larval recruitment relative to associated physical variables. Depth refers to the depth of recruitment. Wind conditions, wave height, temperature and salinity refer to the oceanographic conditions during recruitment. Tide refers to whether recruitment is correlated with the tidal amplitude cycle of spring and neap tides

\begin{tabular}{|c|c|c|c|c|c|c|}
\hline Mechanism & Depth & Wind conditions & Wave height & Temperature & Salinity & Tide \\
\hline Cross-shelf relaxation & Surface & Relaxation & Small & Warm & Low & No \\
\hline Poleward relaxation & Surface & Relaxation & Small & Warm & High & No \\
\hline Poleward downwelling & Surface & Downwelling & Large & Warm & High & No \\
\hline Onshore winds & Surface & Upwelling & Large & Cold & High & No \\
\hline Cross-shelf upwelling & Bottom & Upwelling & Large & Cold & High & No \\
\hline Internal waves & Surface & Anytime & Any size & Warm & High & Yes \\
\hline Internal bores & Bottom & Anytime & Any size & Cold & High & Yes \\
\hline
\end{tabular}


Pacific coast of the USA (Pineda 1994, 1995, 1999, Shanks 2002, 2006, Ladah et al. 2005). Internal waves can deliver larvae to shore in warm, saline surface waters during any phase of the tidal amplitude cycle (Table 1; Rosenfeld 1990, Shanks 2002). Internal bores can be most effective at delivering larvae residing in deep, cold saline water to shore especially during spring tides along this coast (Table 1; Pineda 1994, 1995).

Interannual variation in the number of recruits also can depend on the timing of the spring transition (Shanks \& Roegner 2007). For example, early spring transitions lead to abundant recruitment of Cancer magister postlarvae from offshore, but lower recruitment of several other crab taxa that develop later in the season and close to shore (porcellanids, grapsids, pagurids). Together these patterns demonstrate that intra- and inter-annual variability in larval recruitment is taxon-specific and determined by multiple behavioral and physical transport mechanisms.

In the present study we examine whether larvae of diverse species typically recruit to artificial substrate suspended near the surface and bottom of the water column during variable wind forcing and the tidal amplitude cycle in a recruitmentlimited region of strong, persistent upwelling. We expect that larvae of species

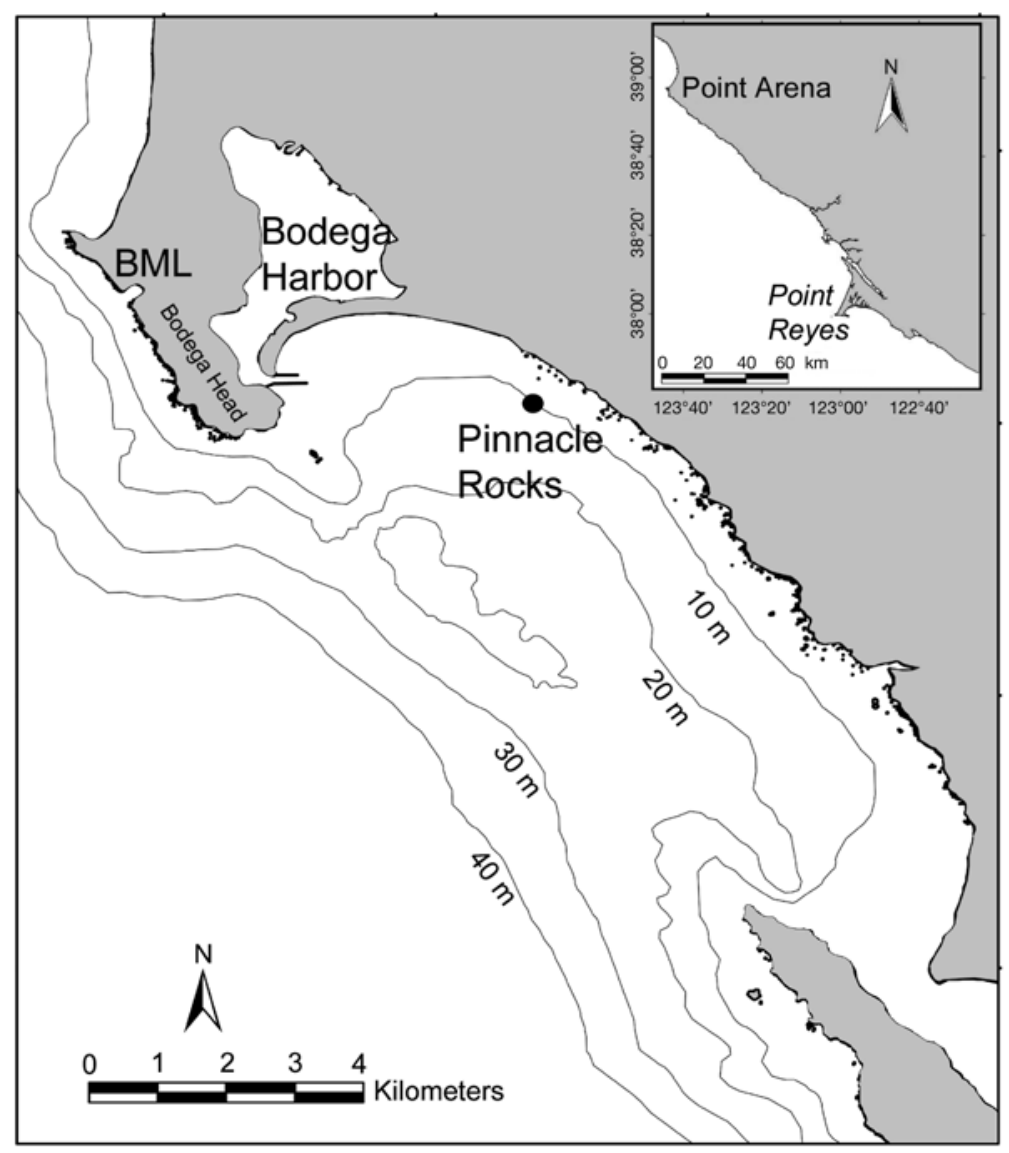

Fig. 1. Location of moorings placed near Pinnacle Rocks along the $10 \mathrm{~m}$ isobath in Bodega Bay, California, USA, during the peak upwelling season from 2001 to 2005. BML: Bodega Marine Laboratory, where salinity was measured

recruiting at the surface may be most likely to recruit during wind relaxation, downwelling, onshore winds, large waves and internal waves, whereas those recruiting at depth may be more likely to recruit via upwelling or internal bores (Table 1). The study was conducted over $5 \mathrm{yr}$ to determine the importance of depth regulation, wind and tides for larval recruitment during years of strong and weak upwelling.

\section{MATERIALS AND METHODS}

Biological sampling. The present study was conducted just offshore of Pinnacle Rocks $\left(38^{\circ} 18.33^{\prime} \mathrm{N}\right.$, $\left.123^{\circ} 01.44^{\prime} \mathrm{W}\right)$ along the eastern shore of northern Bodega Bay in northern California, USA (Fig. 1). The bay is located in a region characterized by a strong, persistent northwesterly wind during the spring and summer. The strong upwelling-favorable wind is mainly equatorward with an onshore component (Dever et al. 2006). Upwelling is active in this windexposed bay, where newly upwelled surface waters move as rapidly offshore and equatorward as on the open coast (Roughan et al. 2005). Bodega Bay faces southwest on the leeward side of a small headland. The bay mouth is approximately $11 \mathrm{~km}$ wide and 20 to $25 \mathrm{~m}$ deep. Tides are mixed semidiurnal with a tidal range (amplitude) of 1.2 to $2.9 \mathrm{~m}$.

Identifying the biophysical mechanisms that regulate larval transport is best determined by daily sampling of recruiting larvae throughout the water column for long periods. This approach is ideal for correlating recruitment to substrates with physical factors and is usually accomplished by sampling from piers and bridges. However, fixed sampling platforms are absent along the exposed coast in this region of strong upwelling, and rough waters preclude regular sampling from boats. As a consequence, larval recruitment in our study area has been sampled from boats at approximately weekly intervals when sea conditions permit. Past studies have been conducted at Bodega Head throughout the peak upwelling season from 1992 to 2002 (Wing et al. 1995, 2003, Lundquist et al. 2000, Mace \& Morgan 2006a). Sampling transi- 
tioned to the lee of the headland in Bodega Bay beginning in 2000. Samples were collected weekly for nearly 5 mo at both locales in 2001 and 2002, when it was determined that recruitment pulses were synchronous among sites (Mace \& Morgan 2006b). In 2003, sampling focused solely on the bay site where it could be conducted regularly and frequently to better detect the relative importance of multiple delivery mechanisms. Daily or bi-daily sampling of larval settlement on moored passive collectors from boats was conducted from 2003 to 2005 during a portion of the peak upwelling season while targeting oceanographic events. This improved our ability to resolve physical transport mechanisms delivering larvae to the study area at the expense of sampling throughout the upwelling season.

Here we report larval recruitment to Bodega Bay for 5 yr: 2001 to 2005 (Table 2). Larval recruitment was monitored weekly for about 5 mo from 6 April to 2 September 2001. Recruitment was monitored weekly for 4 mo from 9 April to 3 September 2002. We previously monitored surface recruitment bi-daily for about $6 \mathrm{wk}$ in 2002 (12 May to 3 July; Mace \& Morgan 2006b) to compare the effect of sampling at different intervals. Sampling was conducted daily for $10 \mathrm{~d}$ from 19 to 28 May 2003. Daily sampling also was conducted for 5 and 7 d during 2004 to target upwelling and a brief downwelling event (31 May to 5 June and 14 to 21 June). The brief daily sampling in 2003 and 2004 complemented our understanding of larval recruitment processes in combination with data collected in the 3 other years of the study. Sampling in 2005 was conducted on alternate days for 2 mo from 9 June to 10 August, combining frequent and long-term sampling.

During the 5 yr study period, 45 upwelling, 31 relaxation and 4 downwelling periods were sampled along with 20 spring and 18 neap tides (Table 2). Oceanographic conditions were variable during 12 sampling periods and the tidal amplitude cycle spanned 6 sampling periods during the entire study. These periods occurred during 2001, 2002 and 2005 when weekly or bi-daily sampling was conducted (Table 2). Sampling did not span a broad range of wind and tidal conditions during daily sampling in 2003 and 2004, but the number of events covered during the brief sampling periods was limited, including targeted sampling that only occurred during spring tides in 2004.

During each year, 3 moorings were spaced approximately $50 \mathrm{~m}$ apart along the $10 \mathrm{~m}$ isobath in sandy substrate adjacent to submerged rocks and the rocky shoreline. Settlement substrate was placed on each mooring $1 \mathrm{~m}$ below the surface and $1 \mathrm{~m}$ above the bottom. Crab and mussel recruits were collected with a mesh bag $(10 \times 30 \mathrm{~cm})$ containing 3 Tuffy kitchen scrub pads. One bag of Tuffys was attached to the top and bottom of the mooring during the first $2 \mathrm{yr}$, and 2 bags of Tuffys were attached at each depth during the last year to increase sampling surface area. Tuffys were rinsed in fresh water to dislodge settlers, which then were preserved in $70 \%$ ethanol. PVC plates $(10 \times 10 \mathrm{~cm})$ covered on both sides with black $3 \mathrm{M}^{\circledR}$ Safety Walk tape collected barnacle recruits in 2001, 2002 and 2005. Barnacles were counted the day of collection.

Recruitment patterns were determined for the most abundant species, including barnacles, mussels and 6 crab taxa. Three species of cancrid crabs recruited abundantly: Cancer magister, C. productus and C. antennarius. Other crabs recruiting abundantly included grapsids (Hemigrapsus nudus, Pachygrapsus crassipes), majids (Pugettia spp.), porcellanids (Petrolisthes spp., Pachycheles spp.) and pagurids (Pagurus spp.). Barnacle recruits were sampled for 3 yr (2001, 2002 and 2005) and consisted of Chthamalus spp., Balanus glandula, B. crenatus and Tetraclita rubescens. Mussel recruits were sampled for the first $4 \mathrm{yr}$ and likely consisted mostly of Mytilus californianus. M. galloprovincialis and M. trossulus occur far less abundantly on exposed coasts in the area, but recruits cannot be reliably distinguished from $M$. californianus using morphological traits. All species were combined

Table 2. Number of samples collected at Bodega Bay, CA, during different oceanographic conditions and tidal amplitude cycles in 2001-2005. Upwelling occurred when equatorward winds were $\geq 5 \mathrm{~m} \mathrm{~s}^{-1}$, relaxation occurred when equatorward winds were $<5 \mathrm{~m} \mathrm{~s}^{-1}$, downwelling occurred when winds were poleward and variable conditions occurred when sampling periods spanned a combination of oceanographic conditions. Spring/neap samples occurred when sampling spanned both phases of the tidal amplitude cycle

\begin{tabular}{|cccccccccc|}
\hline Year & Sampling dates & Interval & Upwelling & Relaxation & Downwelling & Variable & Spring & Neap & Spring/neap \\
\hline 2001 & 6 Apr-2 Sep & Weekly & 8 & 4 & 0 & 4 & 7 & 7 & 3 \\
2002 & 9 Apr-3 Sep & Weekly & 11 & 7 & 0 & 5 & 6 & 6 & 3 \\
2003 & 19-28 May & Daily & 7 & 3 & 0 & 0 & 1 & 1 & 0 \\
2004 & 31 May-5 Jun, & Daily & 8 & 1 & 3 & 0 & 2 & 0 & 0 \\
2005 & 14-21 Jun & 9 Jun-10 Aug & Bi-daily & 11 & 16 & 1 & 3 & 4 & 4 \\
\hline
\end{tabular}


into families or broader taxonomic categories after determining that observed patterns were similar with one exception: recruitment patterns of C. magister differed from $C$. antennarius and C. productus, so this species is presented separately from its 2 conspecifics.

The crabs in the present study spend weeks to months in the plankton, developing through 2 to 5 larval stages and a postlarval stage (megalopa) before returning to the benthos as juveniles. Cancrids recruit to Bodega Bay year-round, peaking in May and June, while grapsids, majids, pagurids and porcellanids peak from May to August (Mace \& Morgan 2006a). Estimated larval periods for cancrids (Cancer antennarius, C. productus, C. magister) range from $\sim 1$ to 4 mo (Lough 1974, Shanks \& Eckert 2005), majids (Pugettia producta, P. richii) are $\sim 7 \mathrm{wk}$, grapsids (Hemigrapsus nudus, H. oregonensis) are $\sim 4 \mathrm{wk}$, porcellanids (Petrolisthes cinctipes, P. eriomerus, Pachycheles rudis) range from $\sim 4$ to $6 \mathrm{wk}$ and pagurids range from $\sim 5$ to 6 wk (Lough 1974, Shanks \& Eckert 2005). The barnacles (Balanus glandula, Chthamalus spp., Tetraclita rubescens) molt through 6 larval stages and a postlarval stage (cyprid), spending $\sim 3$ to 4 wk in the plankton, and the mussels spend $\sim 9 \mathrm{~d}$ developing in the plankton (Strathmann 1987, Shanks \& Eckert 2005).

Physical data. Offshore wind speed, direction and significant wave height were obtained from the National Data Buoy Center (NDBC buoy 46013, $\left.38^{\circ} 13^{\prime} 30^{\prime \prime} \mathrm{N}, 123^{\circ} 19^{\prime} 00^{\prime \prime} \mathrm{W}\right)$. These wind data were used because they are significantly correlated with local wind velocities ( $r=0.58$ to 0.89 for all $5 \mathrm{yr}$ of the study, $\mathrm{p}<0.001)$. They better reflect larger scale wind forcing events, and the cross-shelf transport within the surface mixed layer responds within $7 \mathrm{~h}$ to wind forcing recorded from this buoy (Dever et al. 2006). Wind speeds were smoothed using a 36-h low-pass filter. Periods of upwelling were characterized by equatorward winds $\geq 5 \mathrm{~m} \mathrm{~s}^{-1}$, relaxation by equatorward winds $<5 \mathrm{~m}$ $\mathrm{s}^{-1}$ and downwelling by poleward winds (Table 2). Along- and cross-shore wind stress (dynes $\mathrm{cm}^{-2}$ ) were calculated from hourly data and adjusted to a height of $10 \mathrm{~m}$ above sea level using a neutral stability wind profile, and they were rotated in the alongshore direction to a principal axis of $349.4^{\circ}$ (Dever et al. 2006). Negative values of alongshore wind stress indicate equatorward winds, with larger negative values reflecting stronger upwelling-favorable winds. Positive crossshore wind stress indicates eastward (onshore and upwelling-favorable) wind and negative cross-shore wind stress indicated westward (offshore) wind. Continuous temperature data were taken from Optic StowAway TidbiT thermistors that were attached to one of the settlement moorings at the depth of the recruitment collectors: $1 \mathrm{~m}$ off the bottom (approximately $9 \mathrm{~m}$ deep) and $1 \mathrm{~m}$ below the surface. Temperature $\left( \pm 0.2^{\circ} \mathrm{C}\right)$ was recorded every $6 \mathrm{~min}$. Decreasing temperature values indicate upwelled water in response to increased (negative) equatorward wind stress, and increasing temperature values indicate relaxation or downwelling conditions. Daily averages of salinity $( \pm 0.005)$ were obtained from a Sea-Bird Electronics thermosalinograph (SBE 45 MicroTSG) located in the seawater intake line of the Bodega Marine Laboratory at Bodega Head (Fig. 1). Increasing salinity values indicate salty, upwelled water and internal waves and bores, and decreasing salinity values indicate buoyant, fresher water from relaxation and downwelling.

Bakun coastal upwelling indices $\left(\mathrm{m}^{3} \mathrm{~s}^{-1}\right.$ per $100 \mathrm{~m}$ coastline) for our region $\left(39^{\circ} \mathrm{N}, 125^{\circ} \mathrm{W}\right)$ were obtained from the Pacific Fisheries Environmental Laboratory, Pacific Grove, California (www.pfeg.noaa.gov), for each day and year of the study. Upwelling indices were compared to recruitment during each sampling interval. We began calculating the upwelling index 1 mo before the beginning of the study to capture the planktonic period of recruits settling during our study. The upwelling index for the entire sampling period was determined for each year and compared to the 5 preceding years to place our study in context of a strong El Niño in 1998 and La Niña in 1999. The upwelling index is based on wind stress calculated from synoptic atmospheric pressure fields and provides a large-scale comparison to the localized wind speed measured from NDBC buoy 46013. Positive values indicate upwelling conditions and offshore transport of surface waters resulting from equatorward wind stress, whereas low values indicate relaxation of upwelling and negative values indicate downwelling and the onshore advection of surface waters due to poleward wind stress. The difference between the maximum and minimum estimated tidal height (maximum tidal range) was obtained for the Bodega Harbor entrance from tide prediction software (Tides and Currents v2.0a, Nautical Software) to indicate potential onshore transport by internal tides.

Data analysis. Samples collected repeatedly through time within a year were temporally autocorrelated, so the depth of recruitment for each species was analyzed by a 2 -factor linear mixed model (Systat 12) with depth as the main fixed factor and year as a random blocking factor. Abundances were transformed $\left(\log _{10}[x+1]\right)$ to meet assumptions of homogeneity of variance and normality. Restricted maximum likelihood was used to estimate the covariance matrices and Bayesian Information Criterion (BIC) was used to determine the covariance matrix that fit the model best. An unstructured covariance matrix was fit to year and an autoregressive 1 model was fit to the errors, which led to the lowest BIC for all species. Data were not corrected to account for doubling the number of Tuffys during 
the last 3 yr, because the effects of additional surface area are nonlinear (A. J. Mace unpubl. data). Interannual variation in the number of recruits was not determined, because differences in sampling methods among years likely affected the number of recruits collected. The relative abundance of recruits at the 2 depths is not affected by these differences in area sampled among years, enabling the use of year as a blocking factor.

The timing of recruitment relative to ocean conditions was determined for each taxon and year to determine interspecific and interannual variation in processes regulating larval delivery. During the first $4 \mathrm{yr}$, standard linear correlation was used to relate time-series of recruitment with alongshore and crossshore wind stress, wave height, sea surface temperature, salinity, the Bakun coastal upwelling index and the maximum tidal range averaged across sampling intervals. Larval abundance data did not meet assumptions of normality, so the nonparametric Spearman's rank correlation $(\rho)$ was used for all species and years. Recruitment was cross-correlated with these oceanographic variables during the fifth year, when sampling was sufficiently frequent and extensive to permit this analysis $(n=31)$. Correlations for all years were analyzed for both depths at which recruits were sampled, and data were plotted and compared against correlations for each depth and year.

We also qualitatively assessed the relationship between recruitment and physical variables to determine whether correlations from brief time-series may be due primarily to one event or only a few data points. We expected larval recruitment to be correlated with several related physical variables indicative of upwelling, downwelling and relaxation, so correlations with just one physical variable were viewed as potentially spurious. Several taxa commonly recruited throughout the water column, and correlations and graphs are presented for recruitment at both depths for those species. Most taxa largely recruited either near the surface or the bottom, and results are presented only where abundant recruitment produced reliable results. Although one of our objectives was to determine interannual variability in recruitment processes, a second goal was to identify whether recruitment across years was related to any environmental variables. Therefore, we determined a combined significance level for each variable, depth and species combination for the linear correlations obtained for data gathered from 2000 to 2004 following the $Z$-transform test described by Whitlock (2005).

Although sampling occurred every 2 d in 2005, lags resulting from cross-correlation analyses are presented in days rather than sampling intervals for clarity. The sign of lags indicates whether peaks in re- cruitment occurred after (positive) or before (negative) changes in physical variables. With the exception of cyclic tides, only positive lags are reported because the response variable of recruitment must follow the physical predictor variables.

\section{RESULTS}

\section{Ocean conditions}

The upwelling index in the region of study was much greater during 2001 (mean $\pm \mathrm{SE}=155.5 \pm 9.4)$ and 2002 $(150.9 \pm 10.4)$ than $2003(108.8 \pm 22.6), 2004(119.5 \pm$ $10.9)$ and $2005(118.3 \pm 10.3)$, providing the opportunity to examine how interannual variation in upwelling affected the depth and timing of larval recruitment. The upwelling index values during the present study were intermediate to those during the $5 \mathrm{yr}$ preceding our study, ranging from $100.2 \pm 6.2$ during the strong El Niño of 1998 and $189.3 \pm 11.7$ during the strong La Niña of 1999; therefore, recruitment was investigated during a typical range of upwelling conditions.

In 2005, prevailing equatorward wind stress was strongly cross-correlated with onshore wind stress $(0 \mathrm{~d}$ -0.98 lag), wave height ( $0 \mathrm{~d}-0.665)$, temperature (cold) (+2 d 0.68), salinity (+2d -0.66) and the upwelling index (0 d -0.68, Fig. 2). Two brief periods of fresher water occurred in mid-June and early July and a 3-wk period of fresher water occurred beginning in mid-July coinciding with light and variable alongshore wind stress. In the previous 4 yr, when simple correlations were conducted due to less frequent sampling, equatorward wind stress again was strongly correlated with eastward (onshore) wind stress $(r=-0.98,-0.95$, -0.83 and -0.99 , respectively, $\mathrm{p}<0.001)$, wave height $(\mathrm{r}=-0.64,-0.94,-0.87$ and $-0.84, \mathrm{p}<0.001)$, temperature (cold) $(\mathrm{r}=0.66,0.84,0.76$ and $0.83, \mathrm{p}<0.001)$, salinity $(\mathrm{r}=-0.54,-0.80,-0.22$ and $-0.30, \mathrm{p}<0.001)$ and the upwelling index $(\mathrm{r}=-0.56,-0.74,-0.83$ and $-0.87, \mathrm{p}<$ 0.001). These strong correlations during all $5 \mathrm{yr}$ of the study are typical of upwelling regions, making these useful indicators of upwelling conditions each year. Upwelling conditions were most prevalent during our sampling periods followed by relaxation and downwelling in descending order, except during 2005 when slightly more relaxation than upwelling periods were sampled. Variable conditions were most prevalent when samples were taken weekly in 2001 and 2002.

\section{Depth of recruitment}

All taxa collected either recruited more near the surface or near the bottom during the 5-yr study period 
(Fig. 3). Three taxa recruited more near the bottom of the water column, including barnacles $(F=35.5$, p < $0.001)$, mussels $(F=22.9, \mathrm{p}<0.001)$ and $C$. antennarius/productus $(F=5.9, \mathrm{p}=0.02)$. Of these 3 taxa, the large majority of barnacles $(99.3 \%)$ recruited near the bottom, whereas mussels and Cancer antennarius/ productus also recruited near the surface. The 5 remaining taxa recruited more near the surface of the water column, including porcellanids $(F=25.6, \mathrm{p}<$ $0.001), C$. magister $(F=19.6, \mathrm{p}<0.002)$, pagurids $(F=$ 24.4, p < 0.001), grapsids $(F=52.1, \mathrm{p}<0.001)$ and majids $(F=14.2, \mathrm{p}<0.001)$. The depth of recruitment was consistent among years for 7 of the 8 taxa with the notable exception of $C$. antennarius/productus, which recruited more near the surface rather than the bottom of the water column during the brief sampling season in 2004 .

\section{Cross-correlations of recruitment with ocean conditions, 2005}

Six taxa recruited in sufficient numbers for analysis relative to ocean conditions in 2005, and data are reported only for the depths where recruitment was common (Table 3). Porcellanids and barnacles were most abundant, and the commercially important Cancer magister uncharacteristically failed to recruit during the study period. Barnacles were present in 58.1\% of samples, primarily recruiting in July and tapering off thereafter (Fig. 4). They were the only taxon that recruited almost entirely near the bottom. Recruitment was weakly correlated with the tidal amplitude cycle occurring between neap and spring tides. Recruitment was not significantly correlated with any other physical variable (Table 4 ).

Cancer antennarius/productus recruited throughout the study period and were present in $93.5 \%$ of samples (Table 3, Fig. 4). They commonly recruited throughout the water column but were most abundant near the bottom. Recruitment near the bottom occurred within $2 \mathrm{~d}$ of the appearance of large waves during upwelling and 4 to $6 \mathrm{~d}$ after the appearance of saline water (Table 4). Recruitment at the surface peaked within $2 \mathrm{~d}$ of equatorward and onshore wind stress, within $2 \mathrm{~d}$ of the occurrence of large waves, within $2 \mathrm{~d}$ after upwelling and within $4 \mathrm{~d}$ after the appearance cold saline water. Larvae recruited near the surface less than $2 \mathrm{~d}$ after neap tides and were notably absent during the longest period of relaxation in mid-June.

Porcellanid larvae were the most dominant taxon (88.2\% of all recruits) and were present in $96.8 \%$ of samples (Table 3). Most porcellanid larvae recruited in June; recruitment occurred throughout the water col- umn but was concentrated near the bottom (Fig. 4). Recruitment near the surface and bottom occurred within $4 \mathrm{~d}$ after peak equatorward and onshore wind stress and the appearance of large waves in cold, saline water at both depths (Table 4). The lag relative to large waves was shorter near the bottom, occurring within $2 \mathrm{~d}$. Recruitment was not significantly related to the upwelling index or maximum tidal range.

Pagurids were present in $71 \%$ of samples and peaked in June when they recruited throughout the

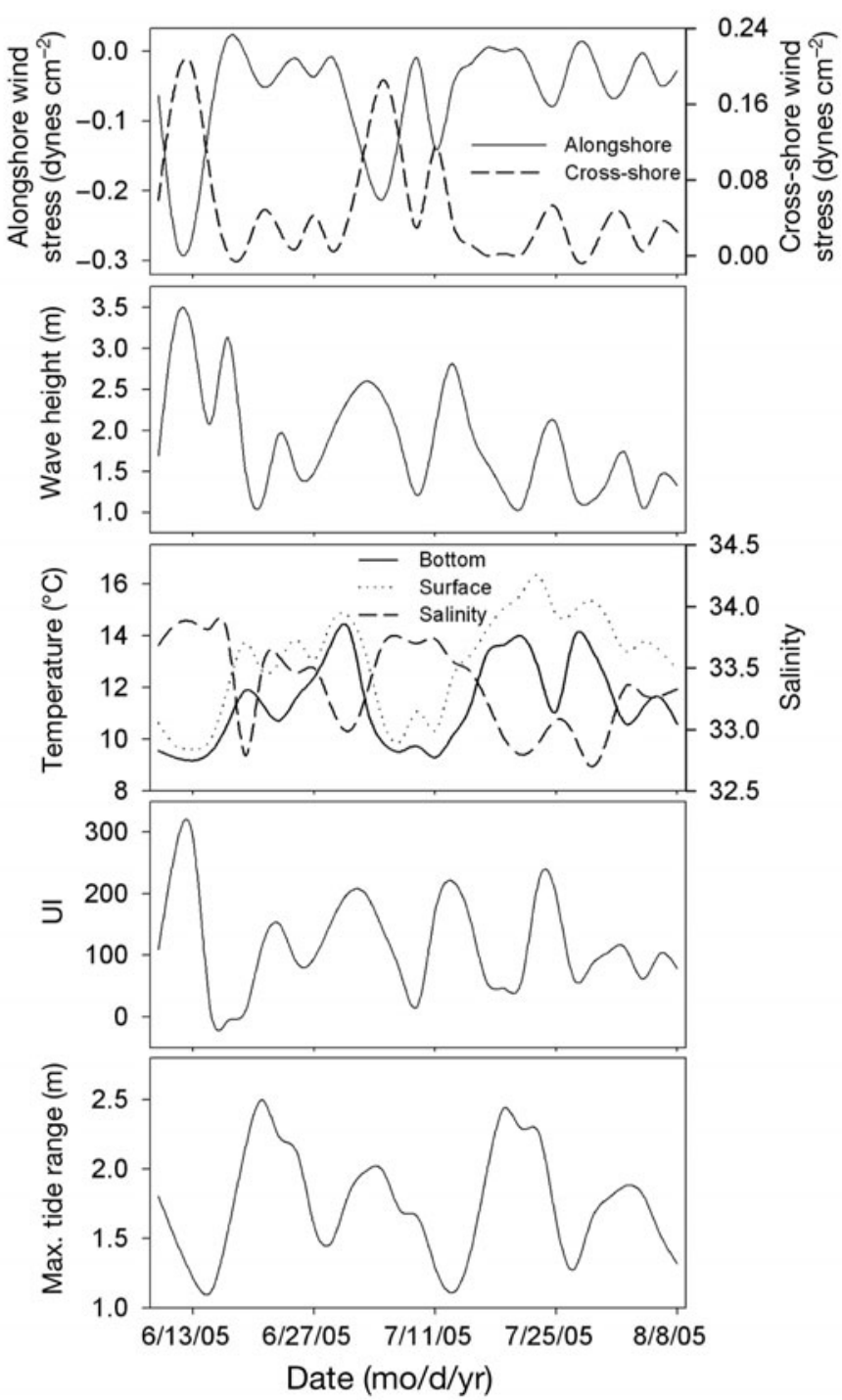

Fig. 2. Daily averages of ocean conditions near Bodega Marine Laboratory from 9 June to 10 August 2005: alongshore and cross-shore wind stress (dynes $\mathrm{cm}^{-2}$ ) rotated to $349.4^{\circ}$ from NDBC buoy 46013 (negative alongshore values indicate increasing equatorward wind stress); significant wave height (m) from NDBC buoy 46013; temperature at the depth of the recruitment collectors $(1 \mathrm{~m}$ below the surface and $1 \mathrm{~m}$ above the bottom) off Pinnacle Rock and salinity; Bakun upwelling indices (UI) for $39^{\circ} \mathrm{N}, 125^{\circ} \mathrm{W}\left(\mathrm{m}^{3} \mathrm{~s}^{-1}\right.$ per $100 \mathrm{~m}$ of coastline); and maximum daily tidal range $(\mathrm{m})$ 

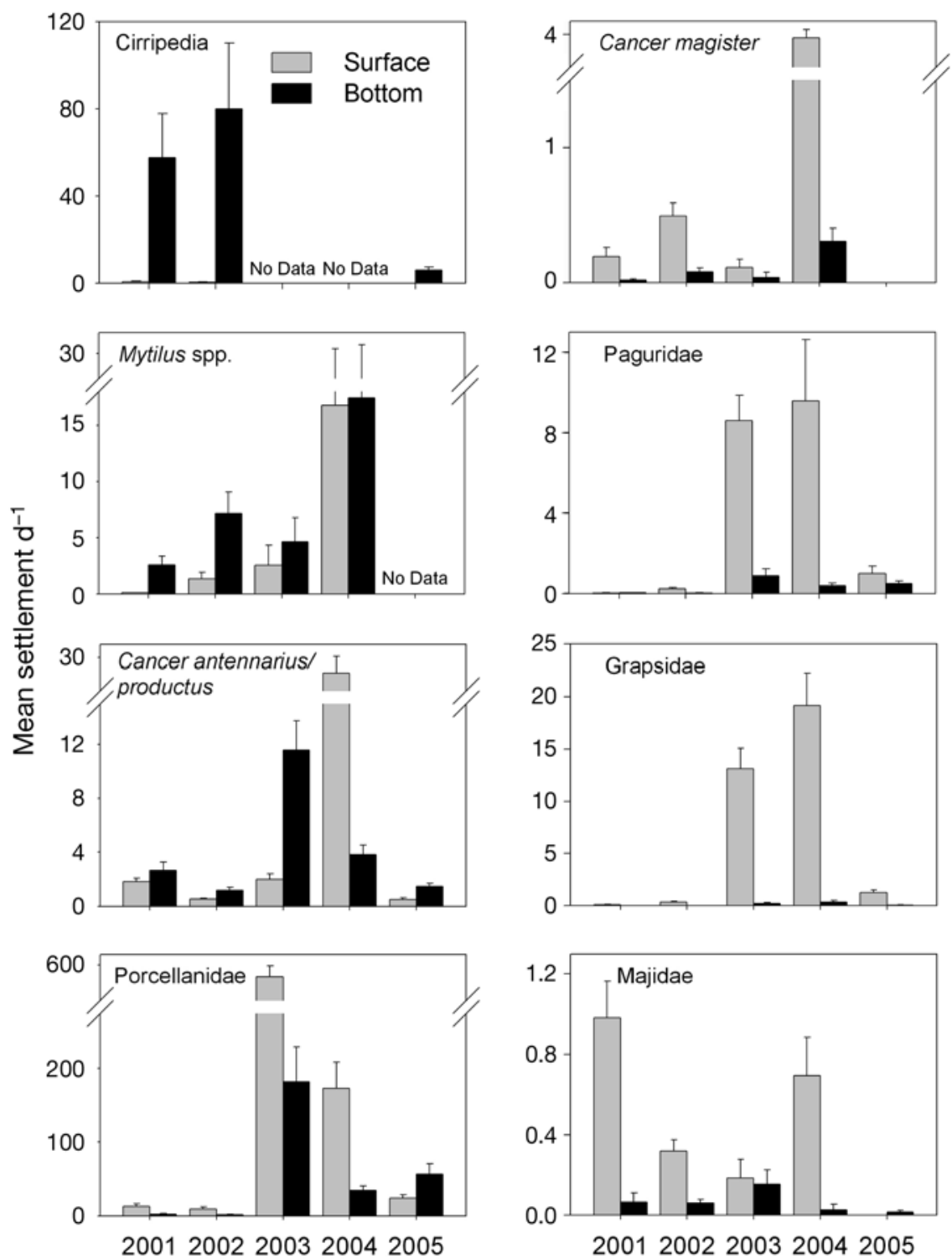

Fig. 3. Depth of recruitment for 8 taxa collected. Mean larval recruitment (+SE) per day of barnacles, mussels, Cancer magister, C. antennarius/productus and porcellanid, pagurid, grapsid and majid crabs to artificial collectors near the $10 \mathrm{~m}$ isobath in Bodega Bay from 2001 to 2005

Table 3. Abundance of crab and barnacle postlarvae collected at Pinnacle Rock in Bodega Bay (surface and bottom data combined) during 2005. Abundance data are presented as total mean abundance $( \pm \mathrm{SE})$ over the 62-d sampling period (average of collectors from 3 moorings, $n=3$ ) and mean $( \pm$ SE) per sampling period (average of 3 collectors from each $2-d$ period, $n=31$ ). The percentage of total crab settlement (\% total) that each taxon represented and the percentage of trips (\% time) during the study that the taxa were present are also presented

\begin{tabular}{|c|c|c|c|c|}
\hline Taxon & Total mean abundance & Mean abundance trip ${ }^{-1}$ & $\%$ total & $\%$ time \\
\hline Porcellanidae & $5064.0 \pm 228.1$ & $163.4 \pm 61.4$ & 88.2 & 96.8 \\
\hline Cirripedia & $371.3 \pm 34.3$ & $12.0 \pm 4.5$ & 6.5 & 58.1 \\
\hline Cancer antennarius/productus & $123.3 \pm 12.3$ & $4.0 \pm 0.8$ & 2.1 & 93.5 \\
\hline Paguridae & $94.3 \pm 18.6$ & $3.0 \pm 1.5$ & 1.6 & 71.0 \\
\hline Grapsidae & $85.3 \pm 2.7$ & $2.8 \pm 0.8$ & 1.5 & 80.6 \\
\hline Majidae & $1.0 \pm 0.58$ & $0.03 \pm 0.02$ & 0.1 & 9.7 \\
\hline
\end{tabular}



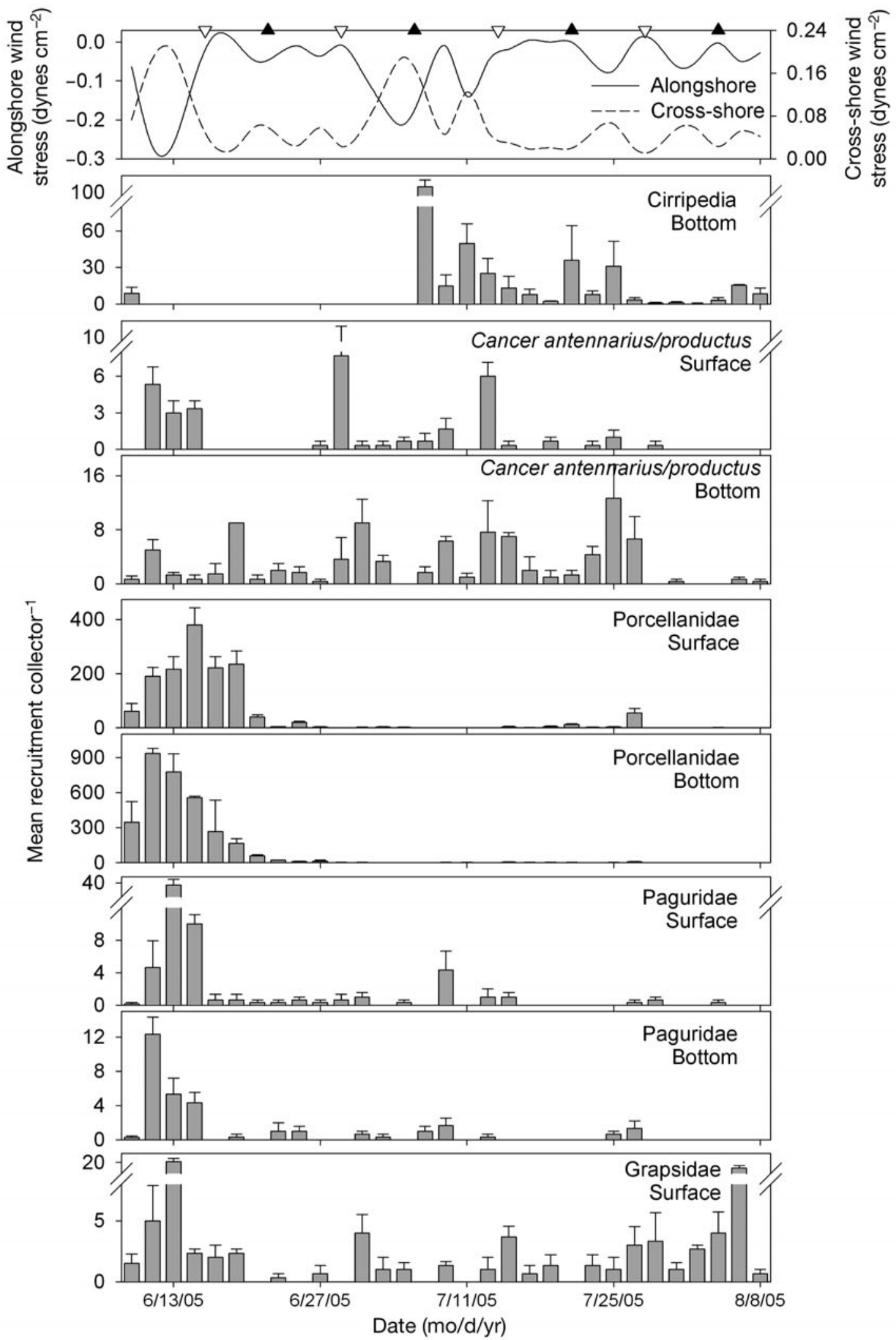

Fig. 4. Mean larval recruitment (+SE) of barnacles, Cancer antennarius/productus and porcellanid, pagurid, and grapsid crabs to artificial collectors in Bodega Bay relative to alongshore and cross-shelf wind stress $\left(\right.$ dynes $\left.\mathrm{cm}^{-2}\right)$ and spring $(\boldsymbol{\Delta})$ and neap $(\nabla)$ tides for 2 mo during 2005; sampling occurred bi-daily. Barnacles and grapsids largely recruited to the bottom and surface, respectively. Majids recruited sparsely and are not shown 
Table 4. Cross-correlation of recruitment of 6 taxa to artificial collectors near the surface and bottom of the water column relative to alongshore and cross-shore wind stress, wave height, temperature, salinity, upwelling index and maximum tidal range for 2 mo during 2005 in northern California. Lags represent the number of days and the sign indicates whether peaks in recruitment occurred after (positive) or before (negative) changes in physical variables. Positive and negative correlations with alongshore wind stress indicate recruitment during poleward (relaxation) and equatorward winds (upwelling), respectively. Positive and negative correlations with cross-shore wind stress indicate recruitment during eastward (onshore) and westward (offshore) winds, respectively. Positive and negative correlations with wave height indicate recruitment during larger and smaller waves, respectively. Positive and negative correlations with temperature indicate recruitment in warm water (relaxation) and cold water (upwelling), respectively. Positive and negative correlations with salinity and upwelling index indicate recruitment in saline water during upwelling and in fresher water during relaxation, respectively. Positive and negative correlations with maximum tidal range indicate recruitment during spring and neap tides, respectively. ns $=$ not significant $(p>0.05)$

\begin{tabular}{|c|c|c|c|c|c|c|c|c|}
\hline \multirow[t]{2}{*}{ Taxon } & \multirow{2}{*}{$\begin{array}{c}\text { Sample } \\
\text { depth }\end{array}$} & \multicolumn{2}{|c|}{ Wind stress } & \multirow{2}{*}{$\begin{array}{l}\text { Wave } \\
\text { height }\end{array}$} & \multirow[t]{2}{*}{ Temperature } & \multirow[t]{2}{*}{ Salinity } & \multirow{2}{*}{$\begin{array}{l}\text { Upwelling } \\
\text { index }\end{array}$} & \multirow{2}{*}{$\begin{array}{l}\text { Max. tidal } \\
\text { range }\end{array}$} \\
\hline & & Alongshore & Cross-shore & & & & & \\
\hline Cirripedia & Bottom & ns & ns & ns & ns & ns & ns & $\begin{array}{l}-4 \mathrm{~d}-0.264 \\
-2 \mathrm{~d}-0.213\end{array}$ \\
\hline \multirow{3}{*}{$\begin{array}{l}\text { Cancer } \\
\text { antennarius/ } \\
\text { productus }\end{array}$} & Surface & $+0 \mathrm{~d}-0.493$ & $+0 \mathrm{~d} 0.463$ & $+0 \mathrm{~d} 0.581$ & $+2 \mathrm{~d}-0.538$ & $+0 \mathrm{~d} 0.435$ & $+0 \mathrm{~d} 0.445$ & $+0 \mathrm{~d}-0.490$ \\
\hline & & $+2 \mathrm{~d}-0.578$ & $+2 \mathrm{~d} 0.590$ & $+2 \mathrm{~d} 0.314$ & $+4 \mathrm{~d}-0.283$ & $\begin{array}{l}+2 \mathrm{~d} 0.504 \\
+4 \mathrm{~d} 0.329\end{array}$ & $+2 \mathrm{~d} 0.425$ & $+2 \mathrm{~d}-0.290$ \\
\hline & Bottom & ns & ns & $\begin{array}{l}+0 \mathrm{~d} 0.286 \\
+2 \mathrm{~d} 0.278\end{array}$ & ns & $\begin{array}{l}+4 \mathrm{~d} 0.304 \\
+6 \mathrm{~d} 0.394\end{array}$ & $+0 \mathrm{~d} 0.271$ & ns \\
\hline \multirow[t]{6}{*}{ Porcellanidae } & Surface & $+0 \mathrm{~d}-0.221$ & $+0 \mathrm{~d} 0.209$ & $+0 \mathrm{~d} 0.355$ & $+0 \mathrm{~d}-0.307$ & $+2 \mathrm{~d} 0.373$ & ns & ns \\
\hline & & $+2 \mathrm{~d}-0.294$ & $+2 \mathrm{~d} 0.271$ & $+2 \mathrm{~d} 0.535$ & $+2 \mathrm{~d}-0.395$ & $+4 \mathrm{~d} 0.280$ & & \\
\hline & & $+4 \mathrm{~d}-0.364$ & $+4 \mathrm{~d} 0.339$ & $+4 \mathrm{~d} 0.414$ & $+4 \mathrm{~d}-0.420$ & $+6 \mathrm{~d} 0.353$ & & \\
\hline & Bottom & $+0 \mathrm{~d}-0.376$ & $+0 \mathrm{~d} 0.364$ & $+0 \mathrm{~d} 0.418$ & $+0 \mathrm{~d}-0.376$ & $+0 \mathrm{~d} 0.448$ & ns & ns \\
\hline & & $+2 \mathrm{~d}-0.371$ & $+2 \mathrm{~d} 0.368$ & $+2 \mathrm{~d} 0.501$ & $+2 \mathrm{~d}-0.507$ & $+2 \mathrm{~d} 0.455$ & & \\
\hline & & $+4 \mathrm{~d}-0.340$ & $+4 \mathrm{~d} 0.341$ & & $+4 \mathrm{~d}-0.456$ & $+4 \mathrm{~d} 0.423$ & & \\
\hline \multirow[t]{6}{*}{ Paguridae } & Surface & $+0 \mathrm{~d}-0.476$ & $+0 \mathrm{~d} 0.471$ & $+0 \mathrm{~d} 0.445$ & $+0 \mathrm{~d}-0.526$ & $+0 \mathrm{~d} 0.461$ & $+0 \mathrm{~d} 0.281$ & $-2 d-0.383$ \\
\hline & & $+2 \mathrm{~d}-0.681$ & $+2 \mathrm{~d} 0.651$ & $+2 \mathrm{~d} 0.580$ & $+2 \mathrm{~d}-0.615$ & $+2 \mathrm{~d} 0.500$ & $+2 \mathrm{~d} 0.532$ & $+0 \mathrm{~d}-0.461$ \\
\hline & & $+4 \mathrm{~d}-0.418$ & $+4 \mathrm{~d} 0.420$ & & $+4 \mathrm{~d}-0.484$ & $+4 \mathrm{~d} 0.358$ & & $+2 d-0.315$ \\
\hline & Bottom & $+0 \mathrm{~d}-0.616$ & $+0 \mathrm{~d} 0.577$ & $+0 \mathrm{~d} 0.517$ & $+0 \mathrm{~d}-0.438$ & $+0 \mathrm{~d} 0.511$ & $+0 \mathrm{~d} 0.356$ & $-4 \mathrm{~d}-0.312$ \\
\hline & & $+2 \mathrm{~d}-0.556$ & $+2 \mathrm{~d} 0.553$ & $+2 \mathrm{~d} 0.377$ & $+2 \mathrm{~d}-0.472$ & $+2 \mathrm{~d} 0.407$ & $+2 \mathrm{~d} 0.417$ & $-2 \mathrm{~d}-0.421$ \\
\hline & & $+4 \mathrm{~d}-0.295$ & $+4 \mathrm{~d} 0.284$ & & & & & $+0 \mathrm{~d}-0.331$ \\
\hline \multirow[t]{2}{*}{ Grapsidae } & Surface & $+0 \mathrm{~d}-0.272$ & $+0 \mathrm{~d} 0.215$ & $+0 \mathrm{~d} 0.281$ & ns & ns & $+0 \mathrm{~d} 0.222$ & $+0 \mathrm{~d}-0.359$ \\
\hline & & $+2 \mathrm{~d}-0.256$ & $+2 \mathrm{~d} 0.312$ & & & & $+2 \mathrm{~d} 0.301$ & $+2 \mathrm{~d}-0.339$ \\
\hline \multirow[t]{3}{*}{ Majidae } & Bottom & $+0 \mathrm{~d}-0.302$ & $+0 \mathrm{~d} 0.336$ & $+2 \mathrm{~d} 0.407$ & $+0 \mathrm{~d}-0.217$ & $+0 \mathrm{~d} 0.356$ & $+2 \mathrm{~d} 0.445$ & $-2 \mathrm{~d}-0.302$ \\
\hline & & $+2 \mathrm{~d}-0.518$ & $+2 \mathrm{~d} 0.456$ & & $+2 \mathrm{~d}-0.290$ & $+2 \mathrm{~d} 0.354$ & $+4 \mathrm{~d} 0.268$ & $+0 \mathrm{~d}-0.366$ \\
\hline & & $+4 \mathrm{~d}-0.257$ & $+4 \mathrm{~d} 0.222$ & & $+4 \mathrm{~d}-0.325$ & $+4 \mathrm{~d} 0.331$ & & \\
\hline
\end{tabular}
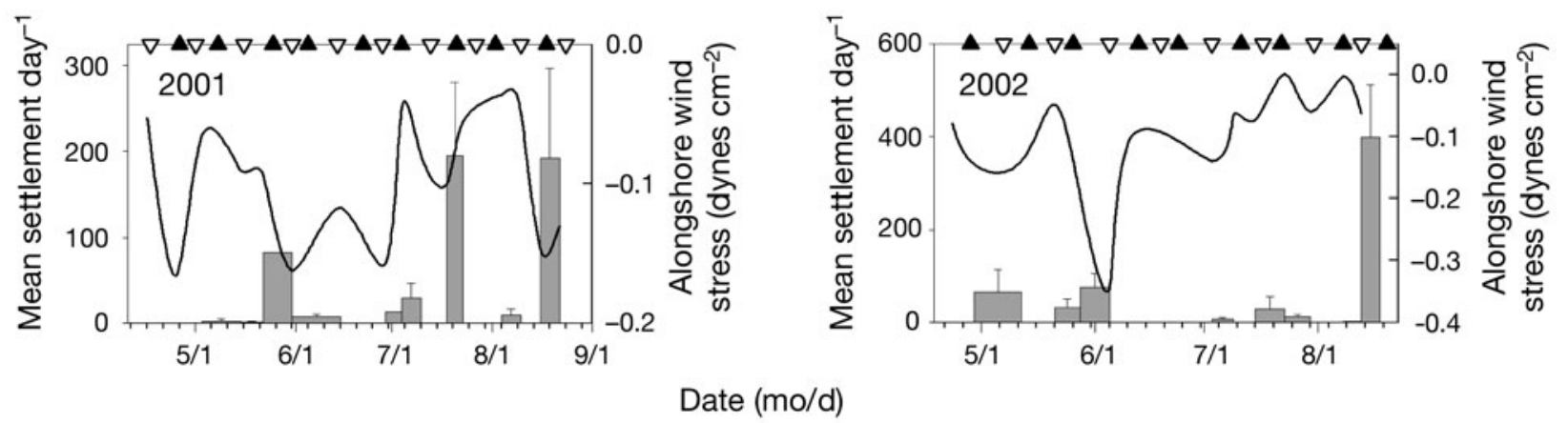

Fig. 5. Chthamalus spp., Balanus glandula, B. crenatus and Tetraclita rubescens. Mean larval recruitment (+SE) of barnacles to artificial collectors in Bodega Bay relative to alongshore wind stress (dynes $\mathrm{cm}^{-2}$ ) and spring $(\boldsymbol{\Delta})$ and neap ( $\left.\nabla\right)$ tides in 2001 and 2002. Barnacles largely recruited near the bottom so surface recruitment is not shown; they were not sampled in 2003 and 2004. The width of the bars indicates the sampling interval. Tick marks on $x$-axes are at $5 \mathrm{~d}$ intervals 
water column (Table 3, Fig. 4). Recruitment at both depths occurred less than $4 \mathrm{~d}$ after equatorward and onshore wind stress in cold saline water and within $2 \mathrm{~d}$ following upwelling and the onset of large waves (Table 4). The lag relative to cold, saline water was shorter near the bottom, occurring within $2 \mathrm{~d}$. Larvae at both depths recruited near neap tides, occurring from $2 \mathrm{~d}$ before to $2 \mathrm{~d}$ after near the surface and 0 to 4 $\mathrm{d}$ before near the bottom.

Grapsids were present in $80.6 \%$ of samples, and recruited mostly near the surface throughout the study period (Table 3, Fig. 4). Recruitment peaked during onshore wind stress and within $2 \mathrm{~d}$ of equatorward wind stress, large waves and upwelling (Table 4). Larvae recruited less than $2 \mathrm{~d}$ after neap tides.

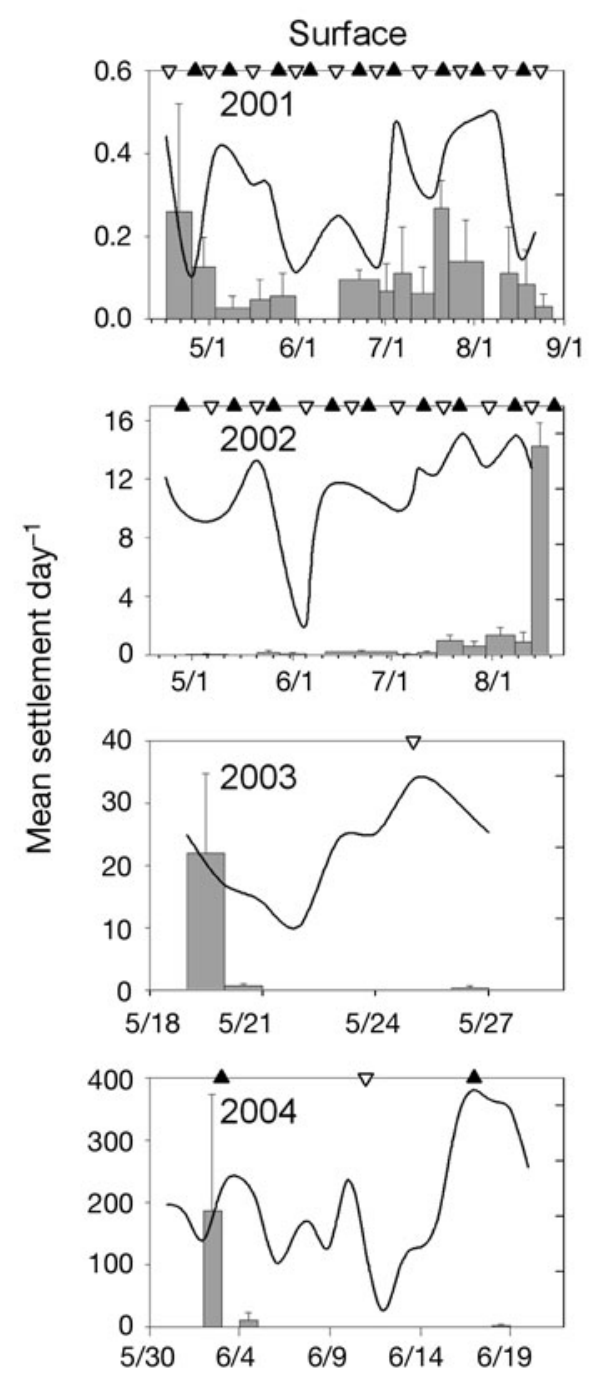

Majids recruited in low numbers only near the bottom of the water column in 2 pulses (Tables $3 \& 4$ ). Recruitment occurred less than $4 \mathrm{~d}$ after peak equatorward and onshore wind stress and the appearance of large waves in cold saline water during upwelling. They also recruited less than $2 \mathrm{~d}$ before neap tides.

\section{Correlations of recruitment with ocean conditions, 2001-2004}

Eight taxa recruited in sufficient numbers for analysis relative to ocean conditions from 2001 to 2004 (Figs. 5 to 9). Interspecific differences in the significance of the 7 physical variables were found for all
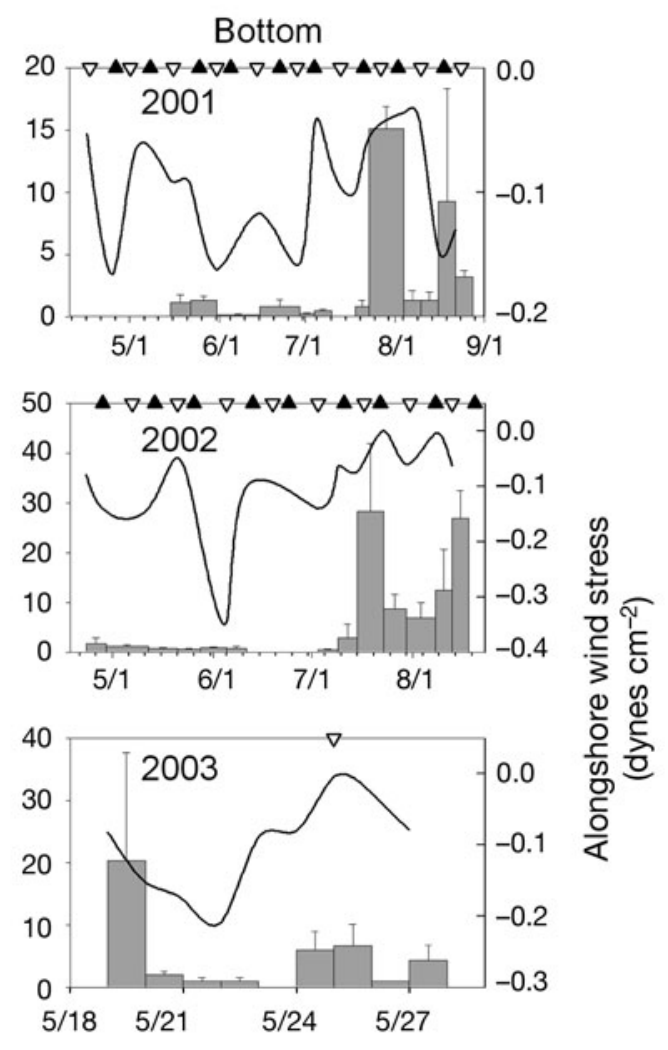

Date $(\mathrm{mo} / \mathrm{d})$

Fig. 6. Mytilus spp. Mean larval recruitment (+SE) of mussels to artificial collectors in Bodega Bay relative to alongshore wind stress (dynes $\mathrm{cm}^{-2}$ ) and spring $(\mathbf{\Lambda})$ and neap $(\nabla)$ tides from 2001 to 2004. The width of the bars indicates the sampling interval and tick marks on 2001 and $2002 x$-axes are at 5 d intervals. Samples were not collected 6-13 June 2004 
years combined (Table 5), suggesting that species recruited via different transport processes. Interannual variation in the relative importance of the variables was evident for species (Table 6), revealing that species recruited via different transport processes among years. Because sampling occurred approximately weekly for 4 or 5 mo $(2001,2002)$ or daily for short durations (2003, 2004), fewer significant correlations resulted than during 2005 when sampling occurred bidaily for 2 mo. Sampling across weekly time periods especially limited our ability to detect recruitment relative to short, infrequent relaxation events. However, because equatorward and cross-shelf wind stress, wave height, seawater temperature, salinity and the upwelling index were well correlated during each year of the study, correlations with just 1 or 2 of the variables could provide a reasonable indication of whether recruitment occurred during upwelling, relaxation or downwelling conditions. Moreover, recruitment patterns relative to these variables were consistent across years for a large majority of the species.

Barnacles almost entirely recruited near the bottom in several pulses throughout the study period (May to August) during 2001 and 2002 (barnacles were not sampled during 2003 and 2004; Fig. 5). Over both years combined, barnacle recruitment was only related to the tidal amplitude cycle (Table 5); it was highly correlated with spring tides in 2001 and nonsignificantly correlated with intermediate tides in 2002 (Table 6).

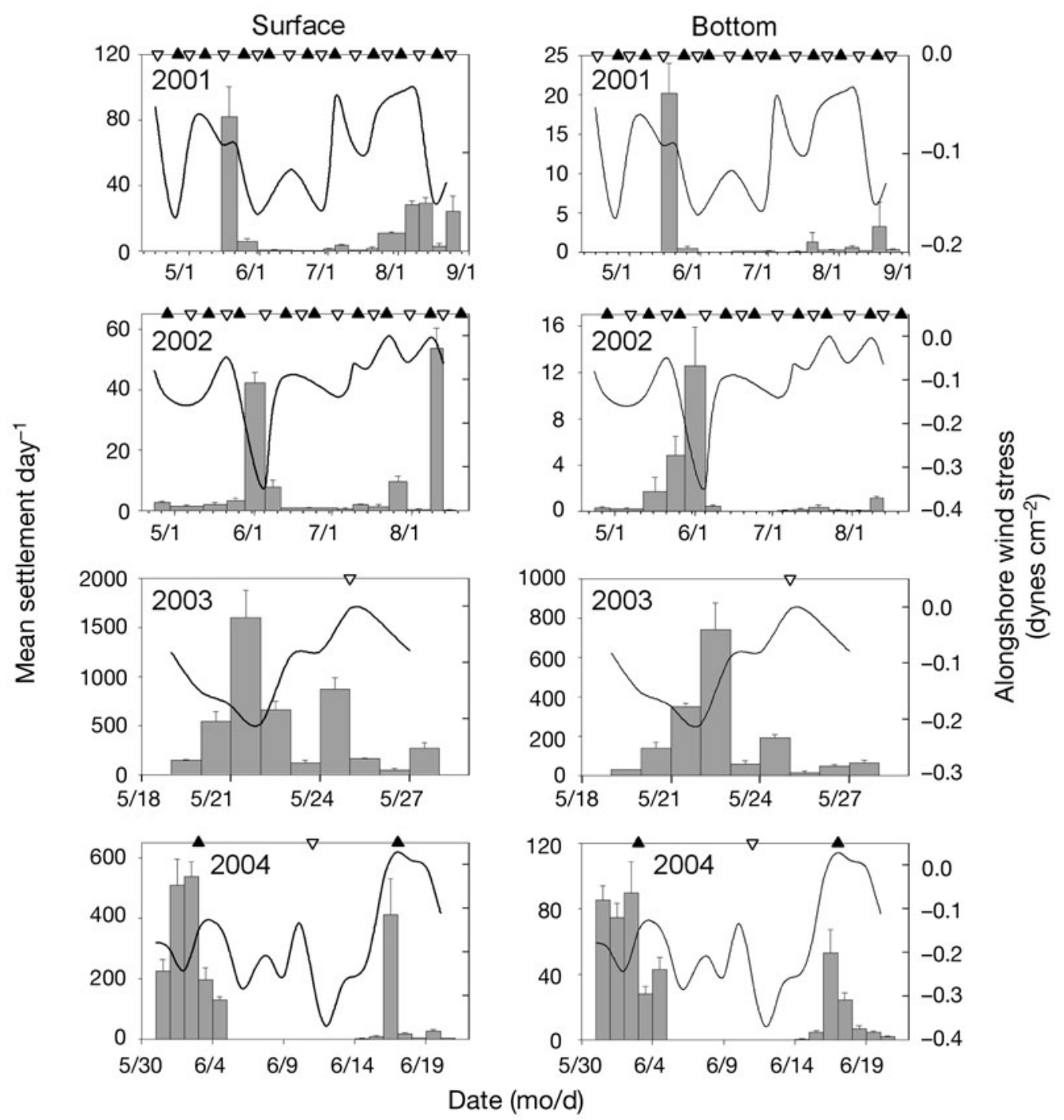

Fig. 7. Petrolisthes spp. and Pachycheles spp. Mean larval recruitment (+SE) of porcellanid crabs to artificial collectors in Bodega Bay relative to alongshore wind stress (dynes $\mathrm{cm}^{-2}$ ) and spring $(\mathbf{\Delta})$ and neap $(\nabla)$ tides from 2001 to 2004 . The width of the bars indicates the sampling interval. Samples were not collected 6-13 June 2004 
For all 4 years combined, mussel recruitment at the surface was related to wave height, salinity and tidal amplitude, and recruitment at the bottom was related to 6 of 7 variables, excluding tidal amplitude (Table 5, Fig. 6). Mussels recruited steadily in low numbers at the surface throughout the 4-mo study period in 2001, and they recruited most abundantly near the bottom in August during relaxation of upwelling (Table 6, Fig. 6). In 2002, mussels recruited steadily in low numbers until August, when peak recruitment occurred at both depths with more recruitment near the bottom. Although recruitment at the surface for all years combined was only related to large waves, salinity and tidal amplitude, recruitment at both depths in this year occurred when prevailing winds were light and sea- ward and waves were small in warm, fresher water during relaxation. In 2003, recruitment initially occurred in saline water throughout the water column and later occurred near the bottom when wind stress weakened $(p=0.07)$ and water was warm $(p=0.07)$. Recruitment near the surface was lowest during neap tide and peaked after spring tides. In 2004, recruitment was abundant but occurred in only 2 pulses in early June near the surface and mid-June near the bottom. Both recruitment events followed equatorward winds at the onset of relaxation but were not significantly correlated with any variables. Despite interannual variability, mussels usually recruited most abundantly near the bottom during relaxation events and at the surface during spring tides.

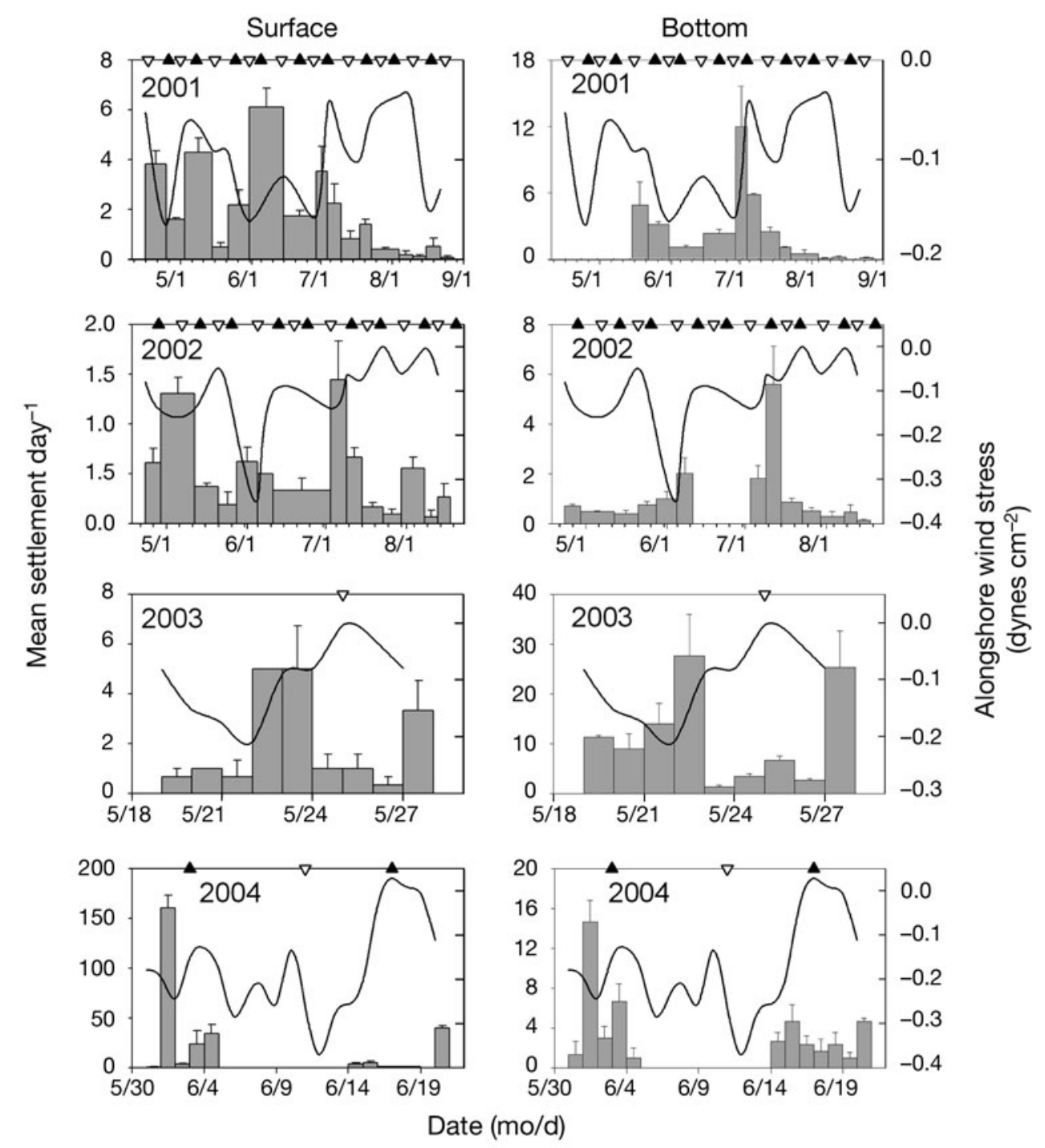

Fig. 8. Cancer antennarius and C. productus. Mean larval recruitment (+SE) of C. antennarius/productus to artificial collectors in Bodega Bay relative to alongshore wind stress (dynes $\mathrm{cm}^{-2}$ ) and spring $(\mathbf{\Delta})$ and neap $(\nabla)$ tides from 2001 to 2004 . The width of the bars indicates the sampling interval and tick marks on 2001 and $2002 x$-axes are at 5 d intervals. Samples were not collected 6-13 June 2004 

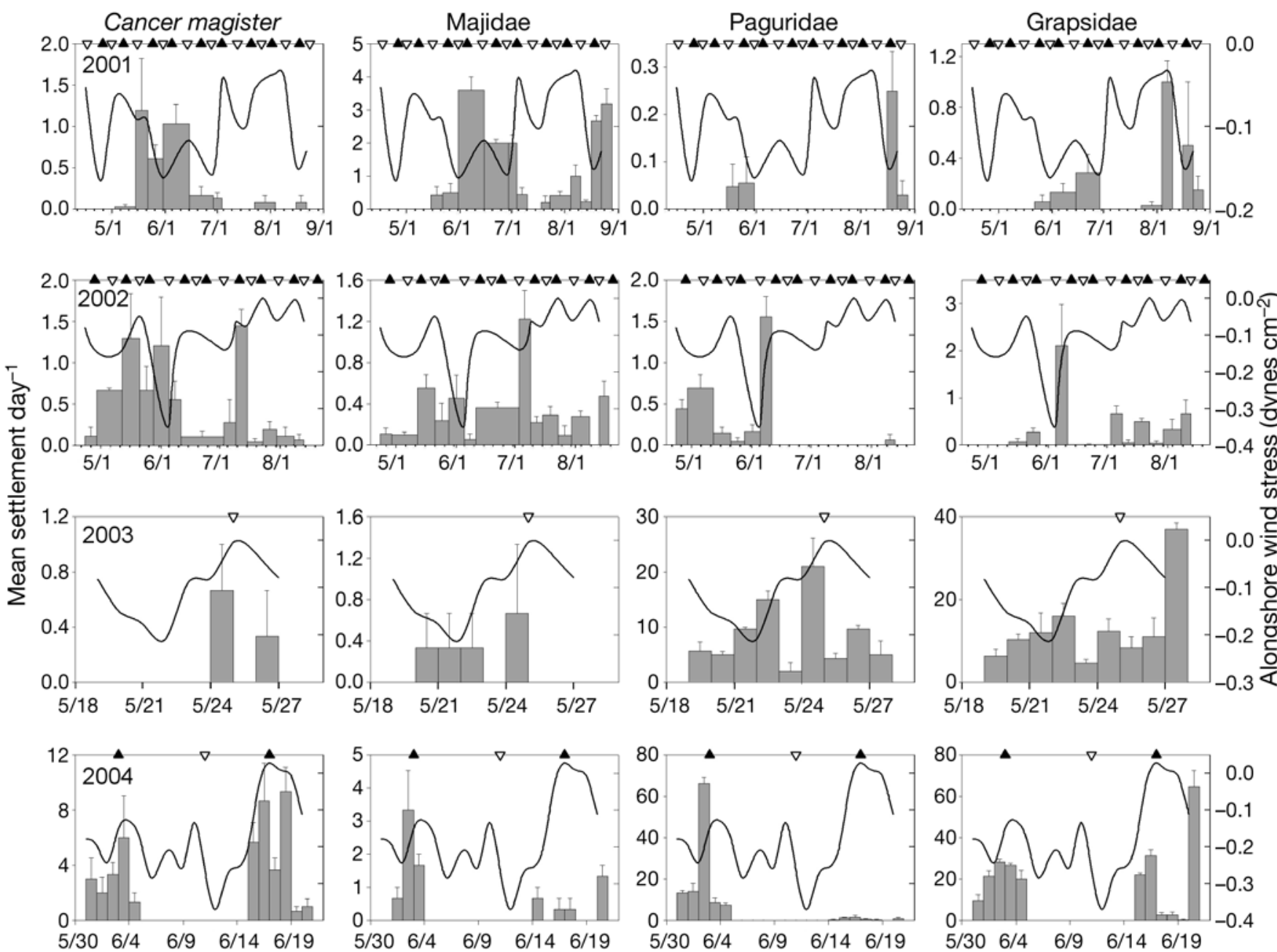

Date $(\mathrm{mo} / \mathrm{d})$

Fig. 9. Mean larval recruitment (+SE) of Cancer magister and majid, pagurid and grapsid crabs to artificial collectors in Bodega Bay relative to alongshore wind stress $\left(\right.$ dynes $\mathrm{cm}^{-2}$ ) and spring $(\mathbf{\Delta})$ and neap $(\nabla)$ tides from 2001 to 2004 . Larvae largely recruited near the surface so bottom recruitment is not shown. The width of the bars indicates the sampling interval and tick marks on 2001 and $2002 x$-axes are at 5d intervals. Samples were not collected 6-13 June 2004

Five decapod taxa usually recruited during upwelling conditions: porcellanids, Cancer antennarius/ productus, C. magister, majids and pagurids. Over all 4 years combined, porcellanid recruitment at both depths was related to seawater temperature and tidal amplitude, and recruitment at the surface also was related to alongshore and cross-shore wind stress (Table 5, Fig. 7). Porcellanids recruited during upwelling conditions in 3 years $(2002-2004)$ and recruited during relaxation in 2001 (Table 6, Fig. 7). In 2001, they recruited in a large pulse throughout the water column at the end of May and to a lesser extent in August. Recruitment peaked near the surface when prevailing winds relaxed $(p=0.06)$ in warm water, and near the bottom only in fresher water. In 2002, they again recruited in a large pulse throughout the water column at the beginning of June during a strong upwelling event and in a second large pulse near the surface in mid-August. Recruitment occurred near the surface only while wind stress was seaward and waves were small and near the bottom only in cold water. In 2003, they recruited at both depths in very large numbers in 2 peaks during and just after upwelling. Recruitment occurred throughout the water column while wind stress was equatorward and onshore in cold, saline $(p=0.07)$ surface water during upwelling. Recruitment also peaked near the time of upwelling in 2004. Recruitment occurred in cold water at both depths and in fresher water near the surface. Porcellanid recruitment peaked near the 2 spring tides at both depths. 
Table 5. Z-transform significance values (p-values; see Whitlock 2005) for 2001 to 2004 combined by taxa and depth relative to alongshore and cross-shore wind stress, wave height, temperature, salinity, upwelling index and maximum tidal range during the peak upwelling season in northern California. Significant values $(p<0.05)$ are shown in bold; marginally nonsignificant values $(\mathrm{p}<0.055)$ are shown in bold italics

\begin{tabular}{|c|c|c|c|c|c|c|c|c|}
\hline Taxon & $\begin{array}{c}\text { Sample } \\
\text { depth }\end{array}$ & $\begin{array}{r}\text { Wind } \\
\text { Alongshore }\end{array}$ & $\begin{array}{l}\text { stress } \\
\text { Cross-shore }\end{array}$ & Wave height & Temperature & Salinity & $\begin{array}{l}\text { Upwelling } \\
\text { index }\end{array}$ & $\begin{array}{l}\text { Max. tidal } \\
\text { range }\end{array}$ \\
\hline Cirripedia & Bottom & 0.263 & 0.403 & 1.387 & 1.584 & 1.091 & 0.502 & 0.012 \\
\hline Mytilus spp. & $\begin{array}{l}\text { Surface } \\
\text { Bottom }\end{array}$ & $\begin{array}{l}0.449 \\
\mathbf{0 . 0 0 4}\end{array}$ & $\begin{array}{l}0.317 \\
0.052\end{array}$ & $\begin{array}{l}0.002 \\
0.009\end{array}$ & $\begin{array}{l}0.891 \\
\mathbf{0 . 0 2 8}\end{array}$ & $\begin{array}{l}0.003 \\
0.001\end{array}$ & $\begin{array}{l}0.307 \\
\mathbf{0 . 0 3 4}\end{array}$ & $\begin{array}{l}\mathbf{0 . 0 0 3} \\
1.788\end{array}$ \\
\hline Porcellanidae & $\begin{array}{l}\text { Surface } \\
\text { Bottom }\end{array}$ & $\begin{array}{l}\mathbf{0 . 0 0 2} \\
0.161\end{array}$ & $\begin{array}{r}<\mathbf{0 . 0 0 1} \\
0.066\end{array}$ & $\begin{array}{l}0.239 \\
1.175\end{array}$ & $\begin{array}{r}<0.001 \\
0.003\end{array}$ & $\begin{array}{l}0.49 \\
0.525\end{array}$ & $\begin{array}{l}0.24 \\
0.318\end{array}$ & $\begin{array}{l}0.001 \\
0.016\end{array}$ \\
\hline $\begin{array}{l}\text { Cancer antennarius } \\
\text { /productus }\end{array}$ & $\begin{array}{l}\text { Surface } \\
\text { Bottom }\end{array}$ & $\begin{array}{r}<0.001 \\
0.025\end{array}$ & $\begin{array}{r}<0.001 \\
0.027\end{array}$ & $\begin{array}{l}0.192 \\
0.524\end{array}$ & $\begin{array}{r}<\mathbf{0 . 0 0 1} \\
0.494\end{array}$ & $\begin{array}{l}0.041 \\
0.004\end{array}$ & $\begin{array}{r}0.005 \\
<0.001\end{array}$ & $\begin{array}{l}\mathbf{0 . 0 3 9} \\
0.103\end{array}$ \\
\hline Cancer magister & Surface & 0.017 & 0.159 & 0.108 & 0.005 & $<0.001$ & 0.004 & 0.099 \\
\hline Majidae & Surface & 0.005 & $<0.001$ & 0.891 & 0.012 & 0.242 & 0.08 & 0.052 \\
\hline Paguridae & Surface & $<0.001$ & $<0.001$ & 0.039 & $<0.001$ & 0.454 & 0.054 & $<0.001$ \\
\hline Grapsidae & Surface & 1.656 & 0.055 & 1.522 & 0.535 & 1.368 & 1.946 & 0.408 \\
\hline
\end{tabular}

For all 4 years combined, Cancer antennarius/productus recruitment was related to 6 of 7 variables near the surface, excluding wave height, and 4 of 7 variables near the bottom, excluding wave height, temperature and tidal amplitude (Table 5, Fig. 8), typically recruiting during upwelling conditions (Table 6, Fig. 8). They recruited throughout the water column from May to September in 2001, tapering off in mid-July. They recruited near the bottom in saline waters during upwelling and near the surface only in cold waters. In 2002, recruitment occurred at both depths from May through August in cold, saline water while wind stress was equatorward during upwelling. Recruitment near the surface was strongly correlated with variables associated with upwelling (equatorward and onshore winds, upwelling index) as well as neap tides. Two peaks of recruitment occurred throughout the water column in 2003. Most recruitment occurred near the bottom while wind stress was onshore in saline water during upwelling. Recruitment was lowest during neap tides near the bottom and peaked $3 \mathrm{~d}$ before and after neap tides. In early June 2004, C. antennarius/ productus recruited in a very large pulse near the surface during upwelling. Recruitment near the surface occurred when wind stress was equatorward and onshore and waves were large in cold water just before the first spring tide. Recruitment near the bottom occurred when wind stress was onshore $(p=0.06)$ and waves were large $(p=0.08)$ during upwelling.

Cancer magister recruitment from 2001 to 2004 largely occurred near the surface and was related to 4 of the 7 variables, excluding cross-shore wind stress, wave height and tidal amplitude (Table 5, Fig. 9). They typically recruited in low numbers with most recruitment occurring in 2004. In 2001, recruitment primarily occurred from May through June while wind stress was equatorward and onshore and waves were large in saline water during upwelling (Table 6, Fig. 9). In 2002, recruitment primarily occurred from May through early June and in a pulse during mid-July. Recruitment occurred in cold, saline water during upwelling. Recruitment was sparse in 2003, occurring only in 2 pulses, and was weakly correlated with cold water $(p=0.06)$ during relaxation $(p=0.06)$. Recruitment occurred in warm, saline water with the highest recruitment occurring during downwelling in 2004. Thus recruitment occurred during upwelling during the first 2 years of extended sampling, whereas it was spotty in 2003 and greatest during a downwelling event in the short sampling period in 2004.

From 2001 to 2004, majids largely recruited near the surface and steadily in low numbers throughout sampling periods each year (Fig. 9). Recruitment was related to 4 of the 7 variables, excluding wave height, salinity and upwelling index (Table 5), and they typically recruited during upwelling conditions when wind stress was onshore (Table 6). Majids also recruited when wind stress was equatorward in saline water during upwelling in 2001, and in cold water in 2003. In 2004, recruitment peaked during the first sampling interval also while wind stress was equatorward in cold water during spring tide.

Pagurid recruitment from 2001 to 2004 was related to 6 of the 7 variables, excluding salinity (Table 5, Fig. 9). They largely recruited near the surface and episodically in low numbers during the first 2 years of the study. Recruitment was 1 to 2 orders of magnitude greater during the last 2 years, despite the shorter sampling periods. Recruitment was not significantly correlated with any oceanographic variable in 2001 when 
recruitment was sparse (Table 6, Fig. 9). In 2002, recruitment occurred in 2 pulses at the beginning of May and June while wind stress was equatorward and onshore and waves were large in cold, saline surface water during upwelling and neap tides. In 2003, pagurids recruited while wind stress was onshore in cold water. In 2004, they recruited during the first sampling interval while wind stress was equatorward and onshore and waves were large in cold surface water during spring tide. Thus pagurids typically recruited during upwelling conditions.

As with pagurids, grapsids recruited near the surface in low numbers during the first 2 years of the present study, and they were much more abundant during the last 2 years (Fig. 9). Few grapsids recruited before June during the first 2 years. For all 4 years combined,

Table 6. Spearman correlations of recruitment by 8 taxa relative to alongshore and cross-shore wind stress, wave height, temperature, salinity, upwelling index and maximum tidal range during the peak upwelling season from 2001 to 2004 in northern California. Significant correlations $(\mathrm{p}<0.05)$ are shown in bold; marginally nonsignificant correlations $(0.05<\mathrm{p}<0.07)$ are shown in bold italics. See Table 3 for explanations of positive and negative correlations. Barnacles were not sampled in 2003 and 2004

\begin{tabular}{|c|c|c|c|c|c|c|c|c|c|}
\hline Taxon & Year & $\begin{array}{c}\text { Sample } \\
\text { depth }\end{array}$ & $\begin{array}{r}\text { Wind } \\
\text { Alongshore }\end{array}$ & $\begin{array}{l}\text { stress } \\
\text { Cross-shore }\end{array}$ & $\begin{array}{l}\text { Wave } \\
\text { height }\end{array}$ & Temperature & Salinity & $\begin{array}{l}\text { Upwelling } \\
\text { index }\end{array}$ & $\begin{array}{l}\text { Max. tidal } \\
\text { range }\end{array}$ \\
\hline Cirripedia & $\begin{array}{l}2001 \\
2002\end{array}$ & $\begin{array}{l}\text { Bottom } \\
\text { Bottom }\end{array}$ & $\begin{array}{l}-0.355 \\
-0.292\end{array}$ & $\begin{array}{l}0.337 \\
0.214\end{array}$ & $\begin{array}{r}-0.122 \\
0.049\end{array}$ & $\begin{array}{r}0.127 \\
-0.021\end{array}$ & $\begin{array}{r}0.127 \\
-0.129\end{array}$ & $\begin{array}{l}0.132 \\
0.370\end{array}$ & $\begin{array}{r}\mathbf{0 . 6 8 7} \\
-0.352\end{array}$ \\
\hline Mytilus spp. & $\begin{array}{l}2003 \\
2004\end{array}$ & $\begin{array}{l}\text { Surface } \\
\text { Bottom } \\
\text { Surface } \\
\text { Bottom } \\
\text { Surface } \\
\text { Bottom } \\
\text { Surface } \\
\text { Bottom }\end{array}$ & $\begin{array}{r}-0.081 \\
0.169 \\
\mathbf{0 . 5 0 9} \\
\mathbf{0 . 4 4 9} \\
-0.030 \\
\mathbf{0 . 3 6 0} \\
0.106 \\
-0.287\end{array}$ & $\begin{array}{r}0.034 \\
-0.160 \\
-\mathbf{0 . 4 3 3} \\
\mathbf{- 0 . 3 7 5} \\
-0.258 \\
-0.185 \\
-0.078 \\
0.266\end{array}$ & $\begin{array}{r}-0.109 \\
0.076 \\
-\mathbf{0 . 4 4 4} \\
-\mathbf{0 . 3 0 0} \\
0.208 \\
-0.283 \\
-0.187 \\
0.271\end{array}$ & $\begin{array}{r}-0.053 \\
0.124 \\
\mathbf{0 . 5 7 5} \\
\mathbf{0 . 6 3 9} \\
-0.007 \\
\mathbf{0 . 3 5 4} \\
-0.052 \\
-0.046\end{array}$ & $\begin{array}{r}0.197 \\
-0.283 \\
-\mathbf{0 . 6 2 7} \\
\mathbf{- 0 . 5 8 5} \\
\mathbf{0 . 4 5 6} \\
\mathbf{0 . 4 3 2} \\
-0.167 \\
0.176\end{array}$ & $\begin{array}{r}-0.064 \\
-\mathbf{0 . 3 9 5} \\
-0.238 \\
-\mathbf{0 . 3 0 1} \\
0.289 \\
-0.098 \\
-0.288 \\
0.227\end{array}$ & $\begin{array}{l}\mathbf{0 . 2 8 4} \\
0.060 \\
0.229 \\
0.182 \\
\mathbf{0 . 5 4 9} \\
0.105 \\
0.194 \\
0.035\end{array}$ \\
\hline Porcellanidae & $\begin{array}{l}2001 \\
2002 \\
2003 \\
2004\end{array}$ & $\begin{array}{l}\text { Surface } \\
\text { Bottom } \\
\text { Surface } \\
\text { Bottom } \\
\text { Surface } \\
\text { Bottom } \\
\text { Surface } \\
\text { Bottom }\end{array}$ & $\begin{array}{r}\mathbf{0 . 2 9 0} \\
0.157 \\
0.261 \\
0.021 \\
-\mathbf{0 . 5 6 3} \\
\mathbf{- 0 . 7 5 5} \\
-0.184 \\
-0.163\end{array}$ & $\begin{array}{r}-0.234 \\
-0.096 \\
-\mathbf{0 . 3 3 5} \\
-0.046 \\
\mathbf{0 . 8 4 1} \\
\mathbf{0 . 9 0 9} \\
0.301 \\
0.233\end{array}$ & $\begin{array}{r}-0.075 \\
-0.026 \\
-\mathbf{0 . 2 9 0} \\
-0.064 \\
-0.019 \\
0.095 \\
0.266 \\
0.203\end{array}$ & $\begin{array}{r}\mathbf{0 . 6 8 2} \\
0.041 \\
0.127 \\
\mathbf{- 0 . 4 1 6} \\
\mathbf{- 0 . 7 0 5} \\
\mathbf{- 0 . 5 5 9} \\
\mathbf{- 0 . 5 6 1} \\
\mathbf{- 0 . 3 4 3}\end{array}$ & $\begin{array}{r}0.075 \\
-\mathbf{0 . 3 8 9} \\
-0.148 \\
0.080 \\
\mathbf{0 . 3 5 5} \\
-0.015 \\
-\mathbf{0 . 6 1 1} \\
-0.169\end{array}$ & $\begin{array}{r}0.169 \\
-0.183 \\
-0.097 \\
0.076 \\
\mathbf{0 . 5 1 1} \\
\mathbf{0 . 4 6 3} \\
0.170 \\
0.057\end{array}$ & $\begin{array}{r}-0.185 \\
-0.198 \\
0.263 \\
0.067 \\
0.284 \\
0.265 \\
\mathbf{0 . 6 9 0} \\
\mathbf{0 . 7 2 7}\end{array}$ \\
\hline $\begin{array}{l}\text { Cancer antennarius/ } \\
\text { productus }\end{array}$ & $\begin{array}{l}2001 \\
2002 \\
2003 \\
2004\end{array}$ & $\begin{array}{l}\text { Surface } \\
\text { Bottom } \\
\text { Surface } \\
\text { Bottom } \\
\text { Surface } \\
\text { Bottom } \\
\text { Surface } \\
\text { Bottom }\end{array}$ & $\begin{array}{l}-0.221 \\
-0.161 \\
-\mathbf{0 . 6 3 5} \\
-\mathbf{0 . 3 2 0} \\
-0.310 \\
-0.312 \\
-\mathbf{0 . 4 4 5} \\
-0.284\end{array}$ & $\begin{array}{r}0.222 \\
-0.100 \\
\mathbf{0 . 5 4 7} \\
0.242 \\
0.284 \\
\mathbf{0 . 4 4 7} \\
\mathbf{0 . 4 7 7} \\
\mathbf{0 . 3 1 7}\end{array}$ & $\begin{array}{r}0.160 \\
0.095 \\
0.183 \\
0.131 \\
-0.013 \\
-0.028 \\
\mathbf{0 . 3 4 6} \\
\mathbf{0 . 2 9 5}\end{array}$ & $\begin{array}{r}-\mathbf{0 . 4 5 0} \\
-0.084 \\
\mathbf{- 0 . 4 4 3} \\
\mathbf{- 0 . 3 4 9} \\
0.242 \\
0.142 \\
-\mathbf{0 . 5 4 7} \\
-0.106\end{array}$ & $\begin{array}{r}0.257 \\
\mathbf{0 . 5 4 7} \\
\mathbf{0 . 4 4 1} \\
\mathbf{0 . 4 0 3} \\
-0.279 \\
\mathbf{0 . 5 2 2} \\
0.099 \\
-0.005\end{array}$ & $\begin{array}{l}0.124 \\
\mathbf{0 . 4 8 7} \\
\mathbf{0 . 7 1 1} \\
\mathbf{0 . 3 6 2} \\
0.062 \\
\mathbf{0 . 4 0 1} \\
0.297 \\
\mathbf{0 . 3 3 6}\end{array}$ & $\begin{array}{r}0.208 \\
0.222 \\
\mathbf{- 0 . 5 2 6} \\
0.034 \\
0.002 \\
\mathbf{0 . 4 7 4} \\
\mathbf{0 . 4 2 1} \\
0.265\end{array}$ \\
\hline Cancer magister & $\begin{array}{l}2001 \\
2002 \\
2003 \\
2004\end{array}$ & $\begin{array}{l}\text { Surface } \\
\text { Surface } \\
\text { Surface } \\
\text { Surface }\end{array}$ & $\begin{array}{r}-\mathbf{0 . 3 1 0} \\
-0.278 \\
0.228 \\
0.249\end{array}$ & $\begin{array}{r}\mathbf{0 . 3 6 9} \\
0.175 \\
0.046 \\
-0.242\end{array}$ & $\begin{array}{r}\mathbf{0 . 3 2 2} \\
0.199 \\
-0.135 \\
0.021\end{array}$ & $\begin{array}{r}-0.108 \\
-0.428 \\
-0.365 \\
0.328\end{array}$ & $\begin{array}{r}\mathbf{0 . 3 4 1} \\
\mathbf{0 . 4 6 1} \\
-0.274 \\
\mathbf{0 . 5 9 3}\end{array}$ & $\begin{array}{r}\mathbf{0 . 3 8 0} \\
\mathbf{0 . 3 0 6} \\
-\mathbf{0 . 3 6 5} \\
-0.158\end{array}$ & $\begin{array}{r}0.158 \\
-0.122 \\
-0.321 \\
0.296\end{array}$ \\
\hline Majidae & $\begin{array}{l}2001 \\
2002 \\
2003 \\
2004\end{array}$ & $\begin{array}{l}\text { Surface } \\
\text { Surface } \\
\text { Surface } \\
\text { Surface }\end{array}$ & $\begin{array}{l}-\mathbf{0 . 3 5 4} \\
-0.214 \\
-0.304 \\
-\mathbf{0 . 3 2 0}\end{array}$ & $\begin{array}{l}0.465 \\
0.334 \\
0.399 \\
0.376\end{array}$ & $\begin{array}{r}0.123 \\
-0.024 \\
0.131 \\
0.157\end{array}$ & $\begin{array}{r}0.236 \\
-0.173 \\
-\mathbf{0 . 4 1 2} \\
-\mathbf{0 . 3 2 3}\end{array}$ & $\begin{array}{r}\mathbf{0 . 5 7 8} \\
0.014 \\
0.072 \\
-0.081\end{array}$ & $\begin{array}{l}\mathbf{0 . 3 8 2} \\
0.198 \\
0.221 \\
0.203\end{array}$ & $\begin{array}{r}0.256 \\
-0.204 \\
0.124 \\
\mathbf{0 . 3 5 8}\end{array}$ \\
\hline Paguridae & $\begin{array}{l}2001 \\
2002 \\
2003 \\
2004\end{array}$ & $\begin{array}{l}\text { Surface } \\
\text { Surface } \\
\text { Surface } \\
\text { Surface }\end{array}$ & $\begin{array}{l}-0.212 \\
-\mathbf{0 . 5 7 0} \\
-0.252 \\
-\mathbf{0 . 4 7 6}\end{array}$ & $\begin{array}{l}0.249 \\
\mathbf{0 . 4 5 5} \\
\mathbf{0 . 5 6 8} \\
\mathbf{0 . 5 7 1}\end{array}$ & $\begin{array}{l}0.112 \\
\mathbf{0 . 2 6 8} \\
0.055 \\
\mathbf{0 . 3 7 9}\end{array}$ & $\begin{array}{l}-0.126 \\
-\mathbf{0 . 5 7 4} \\
-\mathbf{0 . 7 0 2} \\
-\mathbf{0 . 7 4 8}\end{array}$ & $\begin{array}{r}-0.127 \\
\mathbf{0 . 5 0 9} \\
-0.200 \\
0.050\end{array}$ & $\begin{array}{r}0.215 \\
\mathbf{0 . 4 4 3} \\
-0.052 \\
0.294\end{array}$ & $\begin{array}{r}0.186 \\
-\mathbf{0 . 4 8 2} \\
-0.102 \\
\mathbf{0 . 7 5 0}\end{array}$ \\
\hline Grapsidae & $\begin{array}{l}2001 \\
2002 \\
2003 \\
2004\end{array}$ & $\begin{array}{l}\text { Surface } \\
\text { Surface } \\
\text { Surface } \\
\text { Surface }\end{array}$ & $\begin{array}{l}-0.102 \\
-0.088 \\
-0.008 \\
-0.143\end{array}$ & $\begin{array}{l}0.199 \\
0.214 \\
0.347 \\
0.209\end{array}$ & $\begin{array}{r}0.089 \\
-0.007 \\
-0.071 \\
0.167\end{array}$ & $\begin{array}{r}0.028 \\
-0.123 \\
-0.187 \\
-\mathbf{0 . 3 6 0}\end{array}$ & $\begin{array}{l}0.067 \\
0.201 \\
0.053 \\
0.307\end{array}$ & $\begin{array}{r}-0.105 \\
0.084 \\
-0.042 \\
0.188\end{array}$ & $\begin{array}{r}0.100 \\
-0.222 \\
-0.014 \\
\mathbf{0 . 4 2 8}\end{array}$ \\
\hline
\end{tabular}


recruitment was not related to any variable (Table 5), and significant correlations were obtained only during 2004 when recruitment was greatest (Table 6). Recruitment that year occurred only in cold water during spring tides.

\section{DISCUSSION}

Multiple biophysical transport processes evidently deliver larvae to shore. Depth regulation is a key determinant affecting the timing of recruitment, because consistent differences in the depth of recruitment were apparent for each of the 8 taxa. The depth of recruitment appears to be under strong behavioral control even in a region of strong upwelling where physical factors are commonly thought to overwhelm larval behavior. The depth of recruitment can be regulated by mean depth preferences and diel vertical migrations. The depth preferences of crustacean postlarvae in our study region were determined during a series of cross-shelf plankton surveys that were conducted during the daytime to the shelf break (Morgan et al. $2009 b)$. The depth of recruitment observed during the present study was the same during the cross-shelf surveys for all but one of these crustacean taxa (pagurids), thereby linking interspecific differences in depth distributions across the shelf with those close to shore. All 6 crab taxa undertake diel vertical migrations (Hobbs et al. 1992, Wing et al. 1998, S. G. Morgan unpubl. data), and the greater abundance of recruits in surface collectors of 5 of these taxa indicate that they may recruit onshore at night, as do many crabs in other regions (Christy \& Morgan 1998, Miller \& Shanks 2004, Porter et al. 2008). In contrast, barnacles and mussels remain deep in the water column throughout the day late in larval development and mostly recruit near the bottom (Morgan et al. 2009b). The depth distributions of recruiting postlarvae in the water column have been correlated with the vertical distributions of adult barnacle species onshore (Grosberg 1982, Miron et al. 1995). It is apparent from the present study that the depth distributions of many taxa other than barnacles play an important role in regulating recruitment and likely determine which of the 7 transport mechanisms delivers larvae to shore.

Some physical transport processes were more common among taxa than others. Larvae are widely believed to recruit near the surface during relaxation of prevailing upwelling winds either as the upwelling front moves onshore (Roughgarden et al. 1988, 1992) or as a coastal boundary current propagates poleward from larval accumulation zones in the lee of headlands (Wing et al. 1995, 2003). However, we found that only 1 of 8 taxa (Mytilus spp.) usually recruited during in- frequent relaxation and downwelling events, and recruitment for this taxon occurred near the bottom during 2 years. Although recruitment of porcellanids occurred during relaxation conditions in 2001, they recruited during upwelling conditions in the other 4 years (2002-2005), as has been previously reported in the study area (Wing et al. 2003). Peak recruitment by the barnacles Balanus glandula and Chthamalus spp. has previously been reported to occur during relaxations in Monterey Bay, California (Farrell et al. 1991), but it was not correlated with wind conditions during any year of our study for these taxa nor for 2 other species of barnacles. The upwelling front in our region remains over the outer shelf (100 to $200 \mathrm{~m}$ isobaths), occasionally breaking down and reforming (Kudela et al. 2006, Lassiter et al. 2006, Papastephanou et al. 2006). During relaxation, currents over the inner and mid-shelf flow northward $\left(\sim 0.1 \mathrm{~m} \mathrm{~s}^{-1}\right)$ and onshore $\left(\sim 0.05 \mathrm{~m} \mathrm{~s}^{-1}\right)$ (Largier et al. 1993, Roughan et al. 2006). Although currents respond quickly $(<1 \mathrm{~d})$ to reversals in wind forcing, relaxation events may be too brief to transport larvae close to shore.

The 5 remaining taxa primarily recruited during upwelling rather than relaxation or downwelling conditions: Cancer magister, C. antennarius/productus, pagurids, grapsids and majids. These taxa recruited during upwelling conditions regardless of whether it was during a year of strong upwelling or relaxation. These results are consistent with a previous 5-yr study that was conducted from 1992 to 1997 at our study location, except that $C$. magister recruited during relaxation conditions during years when relaxation was frequent and prolonged (Wing et al. 2003). During the present study, C. magister recruited in warm, saline water during the brief downwelling period in 2004, but recruitment occurred during upwelling conditions in the previous 3 years. The study period was brief in 2004, and results may not be typical. It now appears that recruitment relative to wind conditions at our location is fairly consistent for most taxa, except C. magister and porcellanids.

Four of the 5 taxa that usually recruited during upwelling arrived mostly near the surface (except Cancer antennarius/productus), where they are believed to be susceptible to offshore and equatorward transport (Parrish et al. 1981, Yoshioka 1982, Roughgarden et al. 1988). Strong northwesterly winds during the daytime may have facilitated shoreward transport by large waves. Cross-correlations with onshore wind stress and wave height were found for 5 of the 6 taxa collected in 2005, and correlations with onshore wind stress and wave height also were evident for the 5 taxa collected during the 4 previous years. Correlations with onshore wind stress and wave height were not evident for barnacles and mussels, which recruit deep 
in the water column, or grapsids, which showed few significant correlations with any variable. In regions with comparatively light upwelling winds, larvae that remain in surface waters could be transported onshore by the sea breeze during the daytime and would not be displaced as far offshore by the weaker land breeze at night (Shanks 1995, Jacinto \& Cruz 2008). Some postlarvae undertake a reverse diel vertical migration that would expedite onshore transport by the sea breeze (Morgan et al. 2009b), because they occur near the surface during the daytime while onshore winds are strongest and descend at night during the weaker offshore land breeze (Shanks 1995). However, during spring and summer in our region of strong, persistent upwelling, equatorward winds blow roughly parallel to the coast with an onshore component, reaching maximum velocity in the afternoon (Dorman et al. 2006). Winds weaken and remain equatorward and parallel to the coast at night. Here, the refraction of shoaling wind-generated waves toward shore may transport larvae onshore, especially when upwelling winds are strong and persistent. The relatively lowlying coastline in our area may increase the onshore wind component, and recruitment by this mechanism may be greater than in areas with higher relief. Thus most taxa recruited onshore near the surface in large waves generated by upwelling-favorable winds rather than during infrequent relaxation or reversal events.

Tides also may play an important role in transporting recruits onshore. Recruitment of 5 of the 6 taxa collected during 2005 (except porcellanids) was significantly cross-correlated with the tidal amplitude cycle, and recruitment of 7 of 8 taxa (except Cancer magister) was correlated with it in at least one of the previous 4 years. As for correlations of recruitment with physical variables associated with wind conditions, correlations with the tides were most evident in 2005, because sampling occurred bi-daily for an extended sampling period. Recruitment of most of these taxa was also cross-correlated with the tidal amplitude cycle in an intensive study conducted at this location in 2002 (Mace \& Morgan 2006b). Although we did not determine whether internal waves and bores were present in either study, they previously have been reported to occur in the study area (Pringle 1999). Our correlations with the tidal amplitude cycle add to the growing evidence of the potential importance of internal tides in transporting larvae onshore along upwelling coasts (Pineda 1994, 1995, 1999, Shanks 2002, 2006, Miller \& Shanks 2004, Ladah et al. 2005). Unlike correlations with physical variables associated with wind conditions, correlations of recruitment with the tidal amplitude cycle were typically not consistent among years. During 2005, recruitment of 4 of the 6 collected taxa occurred during neap tides, while barnacles recruited between neap and spring tides; between 2001 and 2004,7 of the 8 collected taxa recruited during both neap and spring tides. The importance of tides in larval recruitment may also vary regionally. For example, C. magister postlarvae recruit during spring tides in Oregon (Miller \& Shanks 2004) and southern California (Shanks 2006), but not in Bodega Bay or Washington (Roegner et al. 2003). Studies on the role of internal waves and bores in delivering recruits onshore should continue to be conducted repeatedly at many locations for multiple taxa to better understand this transport mechanism.

Abundances of recruits and correlations with winds and tides were not entirely consistent between the present study and a previous study which was conducted at the same locale in 2002 (Mace \& Morgan 2006b). Although porcellanids dominated during both 2002 and 2005, they were nearly 4 times more abundant during the year of weak upwelling in 2005, whereas the other taxa generally were less abundant in 2005, including Cancer magister, which did not recruit. Recruitment patterns relative to wind forcing were similar in the 2 studies for $C$. antennarius/productus and pagurids, which recruited during upwelling conditions, and majids, which recruited during onshore winds. Results differed for C. magister and porcellanids, which generally recruited during upwelling (present study) rather than relaxation conditions. Further, significant correlations of recruitment with physical variables were not obtained for grapsids in either study (Mace \& Morgan 2006b). For tides, results from the 2 studies were similar in that pagurids recruited near neap tides and majids and $C$. magister were not correlated with the maximum tidal range. However, recruitment of C. antennarius/productus was not significantly correlated with the maximum tidal range in the 2002 study, but significant correlations were obtained for grapsids near spring tides and porcellanids between neap and spring tides in the present study. The 2 studies differed in the frequency and duration of sampling as well as whether samples were collected at both the surface and bottom. In the earlier study, we sampled bi-daily for $6 \mathrm{wk}$ and samples were only collected near the surface. In the present study, sampling intervals ranged from daily to weekly, sampling periods ranged from days to months and samples were analyzed separately for the 2 depths. The somewhat different results obtained by the studies highlight the importance of sampling frequently for long durations to improve the reliability of results, even though it may not be practical in open embayments or even feasible on exposed coasts in regions of strong upwelling. Although results typically were similar for species that recruit abundantly at both depths, fewer significant correlations were obtained for species that 
recruit mostly at one depth, making it necessary to separately sample, analyze and present data from near the surface and bottom of the water column.

The present study indicates that recruitment may depend on the interaction of depth of recruitment and the coincidence of larval availability with the occurrence of onshore winds, large waves, upwelled bottom water, relaxation and downwelling events and internal tides. However, the processes responsible for the observed spatial patterns in larval recruitment and adult densities in upwelling regions (Yoshioka 1982, Gaines \& Roughgarden 1985, Roughgarden et al. 1988, 1992, Shkedy \& Roughgarden 1997, Connolly \& Roughgarden 1998, Connolly et al. 2001, Menge et al. 2004) remains elusive. It is becoming increasingly apparent that larvae of most species in upwelling regions are neither passively advected far offshore (Poulin et al. 2002, Tapia \& Pineda 2007, Morgan et al. 2009a,b, Shanks \& Shearman 2009) nor limited to infrequent relaxation conditions (see also Wing et al. 2003, Mace \& Morgan 2006b). An emerging possibility is that the surf zone is a semipermeable barrier to the onshore transport of larvae (Rilov et al. 2008). New comprehensive studies are needed to determine the underlying mechanisms responsible for the observed spatial patterns of recruitment. The role of multiple delivery mechanisms in regulating larval recruitment in time and space should be investigated while determining the fate of larvae after settlement for diverse taxa along upwelling coasts.

Acknowledgements. We thank the many people who contributed countless hours to data collection and sample sorting, including: S. McAfee, M. Carver, L. Akins, S. Jorgensen, T. Westman, V. Metcalf, J. Holbrook, M. Buckhorn, A. Haring, M. Donahue, J. Barlow, D. Baum and D. Kaplan. Discussions with W. White informed our approach to addressing potentially spurious correlations, and correspondence with C. Dorman contributed to our understanding of the effect of prevailing winds and waves on shoreward transport. This research was funded by the National Science Foundation (OCE0326110), California Sea Grant (NA06RG0142), Lerner-Gray American Museum of Natural History, University of California Natural Reserve System, University of California, Davis Graduate Group in Ecology, Golden West Women Flyfishers Foundation and Challenges to California's Natural Resources. This is contribution no. 2462 of the Bodega Marine Laboratory.

\section{LITERATURE CITED}

Becker BJ, Levin LA, Fodrie FJ, McMillan PA (2007) Complex larval connectivity patterns among marine invertebrate populations. Proc Natl Acad Sci USA 104:3267-3272

Broitman BR, Navarrete SA, Smith F, Gaines SD (2001) Geographic variation of southeastern Pacific intertidal communities. Mar Ecol Prog Ser 224:21-34

Christy JH, Morgan SG (1998) Estuarine immigration by crab postlarvae: mechanisms, reliability and adaptive significance. Mar Ecol Prog Ser 174:51-65
Connell JH (1985) The consequences of variation in initial settlement vs. post-settlement mortality in rocky intertidal communities. J Exp Mar Biol Ecol 93:11-45

> Connolly SR, Roughgarden J (1998) A latitudinal gradient in northeast Pacific intertidal community structure: evidence for an oceanographically based synthesis of marine community theory. Am Nat 151:311-326

Connolly SR, Menge BA, Roughgarden J (2001) A latitudinal gradient in recruitment of intertidal invertebrates in the northeast Pacific Ocean. Ecology 82:1799-1813

> Dever EP, Dorman CE, Largier JL (2006) Surface boundary layer variability off northern California, USA during upwelling. Deep-Sea Res II 53:2887-2905

$>$ Doherty P, Fowler T (1994) An empirical test of recruitment limitation in a coral reef fish. Science 263:935-939

> Dorman CE, Dever EP, Largier J, Koracin D (2006) Buoy measured wind, wind stress and curl of the wind stress over the shelf off Bodega Bay, California. Deep-Sea Res II 53:2850-2864

Epifanio CE, Garvine RW (2001) Larval transport on the Atlantic continental shelf of North America: a review. Estuar Coast Shelf Sci 52:51-77

Farrell TM, Bracher D, Roughgarden J (1991) Cross-shelf transport causes recruitment to intertidal populations in central California. Limnol Oceanogr 36:279-288

Gaines S, Roughgarden J (1985) Larval settlement rate: a leading determinant of structure in an ecological community of the marine intertidal zone. Proc Natl Acad Sci USA 82:3707-3711

Graham WM, Largier JL (1997) Upwelling shadows as nearshore retention sites: the example of northern Monterey Bay. Cont Shelf Res 17:509-532

Graham WM, Field JG, Potts DC (1992) Persistent 'upwelling shadows' and their influence on zooplankton distributions. Mar Biol 114:561-570

Grantham BA (1997) Coastal upwelling, larval recruitment, and the dynamics of upper intertidal barnacle communities. PhD dissertation, Stanford University, Stanford, CA

$>$ Grosberg RK (1982) Intertidal zonation of barnacles: the influence of planktonic zonation of larvae on vertical zonation of adults. Ecology 63:894-899

Hickey B (1998) Coastal oceanography of western North America from the tip of Baja California to Vancouver Island. In: Robinson A, Brink KH (eds) The sea: ideas and observations on progress in the study of the seas. John Wiley \& Sons, New York

Hobbs RC, Botsford LW, Thomas A (1992) Influence of hydrographic conditions and wind forcing of the distribution and abundance of Dungeness crab, Cancer magister, larvae. Can J Fish Aquat Sci 49:1379-1388

Jacinto D, Cruz T (2008) Tidal settlement of the intertidal barnacles Chthamalus spp. in SW Portugal: interaction between diel and semi-lunar cycles. Mar Ecol Prog Ser 366:129-135

Kingsford MJ, Leis JM, Shanks A, Lindeman KC, Morgan SG, Pineda J (2002) Sensory environments, larval abilities and local self-recruitment. Bull Mar Sci 70(Suppl):309-340

Kudela RM, Garfield N, Bruland KW (2006) Bio-optical signatures and biogeochemistry from intense upwelling and relaxation in coastal California. Deep-Sea Res II 53: 2999-3022

> Ladah LB, Tapia FJ, Pineda J, Lopez M (2005) Spatially heterogeneous, synchronous settlement of Chthamalus spp. larvae in northern Baja California. Mar Ecol Prog Ser 302: $177-185$

> Lagos NA, Navarrete SA, Véliz F, Masuero A, Castilla JC (2005) Meso-scale spatial variation in settlement and 
recruitment of intertidal barnacles along the coast of central Chile. Mar Ecol Prog Ser 290:165-178

Largier JL, Magnell BA, Winant CD (1993) Subtidal circulation over the northern California shelf. J Geophys Res 98: 18147-18179

Lassiter AM, Wilkerson FP, Dugdale RC, Hogue VE (2006) Phytoplankton assemblages in the CoOP-WEST coastal upwelling area. Deep-Sea Res II 53:3063-3077

Lough R (1974) Dynamics of crab larvae (Anomura, Brachyura) off the central Oregon coast, 1969-1971. PhD dissertation, Oregon State University, Corvallis, OR

Lundquist CJ, Botsford LW, Diehl JM, Lee T, Lockwood DR, Morgan LE, Pearson EL (2000) Effects of El Nino and La Nina on Local Invertebrate Settlement in Northern California. CCOFI Rep 41:1-10

> Mace AJ, Morgan SG (2006a) Larval accumulation in the lee of a small headland: implications for the design of marine reserves. Mar Ecol Prog Ser 318:19-29

Mace AJ, Morgan SG (2006b) Biological and physical coupling in the lee of a small headland: contrasting transport mechanisms for crab larvae in an upwelling region. Mar Ecol Prog Ser 324:185-196

> Menge BA, Blanchette C, Raimondi P, Freidenburg T and others (2004) Species interaction strength: testing model predictions along an upwelling gradient. Ecol Monogr 74: 663-684

Miller JA, Shanks AL (2004) Ocean-estuary coupling in the Oregon upwelling region: abundance and transport of juvenile fish and of crab megalopae. Mar Ecol Prog Ser 271:267-279

Miron G, Boudreau B, Bourget E (1995) Use of larval supply in benthic ecology: testing correlations between larval supply and larval settlement. Mar Ecol Prog Ser 124:301-305

Morgan SG (1995) Life and death in the plankton: larval mortality and adaptation. In: McEdward L (ed) Ecology of marine invertebrate larvae. CRC Press, Boca Raton, FL, p 279-321

Morgan SG (2001) The larval ecology of marine communities. In: Bertness MD, Gaines SD, Hay ME (ed) Marine community ecology. Sinauer, Sunderland, MA, p 159-181

Morgan SG (2006) Larval migration between the Hudson River estuary and New York Bight. In: Levinton JS, Waldman J (ed) The Hudson River Estuary. Cambridge University Press, New York, p 157-170

- Morgan SG, Fisher JL, Mace AJ, Akins L, Slaughter AM, Bollens SM (2009a) Cross-shelf distributions and recruitment of crab postlarvae in a region of strong upwelling. Mar Ecol Prog Ser 380:173-185

Morgan SG, Fisher JL, Miller SH, McAfee ST, Largier JL (2009b) Nearshore retention and cross-shelf migration of larvae in a region of strong upwelling and recruitment limitation. Ecology 90 (in press)

Papastephanou KM, Bollens SM, Slaughter AM (2006) Crossshelf distribution of copepods and the role of event-scale winds in a northern California upwelling zone. Deep-Sea Res II 53:3078-3093

Parrish RH, Nelson CS, Bakun A (1981) Transport mechanisms and the reproductive success of fishes in the California Current. Biol Oceanogr 1:175-203

Pineda J (1994) Spatial and temporal patterns in barnacle settlement rate along a southern California rocky shore. Mar Ecol Prog Ser 107:125-138

Pineda J (1995) An internal tidal bore regime at nearshore stations along western USA: predictable upwelling within the lunar cycle. Cont Shelf Res 15:1023-1041

Pineda J (1999) Circulation and larval distribution in internal tidal bore warm fronts. Limnol Oceanogr 44:1400-1414
Porter SS, Eckert GL, Byron CJ, Fisher JL (2008) Comparison of light traps and plankton tows for sampling brachyuran crab larvae in an Alaskan fjord. J Crustac Biol 28:175-179

Poulin E, Palma AT, Leiva G, Narvaez D, Pacheco R, Navarrete SA, Castilla JC (2002) Avoiding offshore transport of competent larvae during upwelling events: the case of the gastropod Concholepas concholepas in central Chile. Limnol Oceanogr 47:1248-1255

Pringle JM (1999) Observations of high-frequency internal waves in the Coastal Ocean Dynamics Region. J Geophys Res 104:5263-5281

Queiroga H, Blanton J (2004) Interactions between behaviour and physical forcing in the control of horizontal transport of decapod crustacean larvae. Adv Mar Biol 47:107-214

Queiroga H, Almeida MJ, Alpuim T, Flores AAV and others (2006) Tide and wind control of megalopal supply to estuarine crab populations on the Portuguese west coast. Mar Ecol Prog Ser 307:21-36

Rilov G, Dudas SE, Menge BA, Grantham BA, Lubchenco J, Schiel DR (2008) The surf zone: A semi-permeable barrier to onshore recruitment of invertebrate larvae? J Exp Mar Biol Ecol 361:59-74

- Roegner GC, Armstrong DA, Hickey BM, Shanks AL (2003) Ocean distribution of dungeness crab megalopae and recruitment patterns to estuaries in southern Washington State. Estuaries 26:1058-1070

Rosenfeld LK (1990) Baroclinic semidiurnal tidal currents over the continental shelf off northern California. J Geophys Res 95:22153-22172

Roughan M, Mace AJ, Largier JL, Morgan SG, Fisher JL, Carter ML (2005) Subsurface recirculation and larval retention in the lee of a small headland: a variation on the upwelling shadow theme. J Geophys Res 110, C10027, doi:10.1029/2005JC002898

Roughan M, Garfield N, Largier J, Dever E, Dorman C, Peterson D, Dorman J (2006) Transport and retention in an upwelling region: the role of across-shelf structure. DeepSea Res II 53:2931-2955

> Roughgarden J, Gaines S, Possingham H (1988) Recruitment dynamics in complex life cycles. Science 241:1460-1466

Roughgarden J, Pennington JT, Stoner D, Alexander S, Miller $\mathrm{K}$ (1992) Collisions of upwelling fronts with the intertidal zone: the cause of recruitment pulses in barnacle populations of central California. Acta Oecol 12:35-52

Send U, Beardsley RC, Winant CD (1987) Relaxation from upwelling in the Coastal Ocean Dynamics Experiment. J Geophys Res 92:1683-1698

Shanks AL (1995) Mechanisms of cross-shelf dispersal of larval invertebrates and fishes. In: McEdward L (ed) Ecology of marine invertebrate larvae. CRC, Boca Raton, FL, p 323-367

Shanks AL (2002) Internal tides and the biology of continental shelf waters. In: Castilla JC, Largier JL (eds) The Oceanography and ecology of the nearshore and bays in Chile. Ediciones Universidad Catolica de Chile, Santiago, p 179-203

Shanks AL (2006) Mechanisms of cross-shelf transport of crab megalopae inferred from a time series of daily abundance Mar Biol 148: 1383-1398

> Shanks AL, Brink L (2005) Upwelling, downwelling, and cross-shelf transport of bivalve larvae: test of a hypothesis. Mar Ecol Prog Ser 302:1-12

> Shanks AL, Eckert GL (2005) Population persistence of California Current fishes and benthic crustaceans: a marine drift paradox. Ecol Monogr 75:505-524

Shanks AL, Roegner CG (2007) Recruitment limitation in Dungeness crab populations is driven by variation in atmospheric forcing. Ecology 88:1726-1737 
Shanks AL, Shearman RK (2009) Paradigm lost? Cross-shelf distributions of intertidal invertebrate larvae. Mar Ecol Prog Ser 385:189-204

Shkedy Y, Roughgarden J (1997) Barnacle recruitment and population dynamics predicted from coastal upwelling. Oikos 80:487-498

Sponaugle S, Cowen RK, Shanks A, Morgan SG and others (2002) Predicting self-recruitment in marine populations: Biophysical correlates and mechanisms. Bull Mar Sci 70(Suppl):341-375

Strathmann MF (1987) Reproduction and Development of Marine Invertebrates of the Northern Pacific Coast, University of Washington Press, Seattle, WA

Swearer SE, Shima JS, Hellberg ME, Thorrold SR and others (2002) Evidence of self-recruitment in demersal marine populations. Bull Mar Sci 70(Suppl):251-271

Tapia FJ, Pineda J (2007) Stage-specific distribution of barnacle larvae in nearshore waters: potential for limited dispersal and high mortality rates. Mar Ecol Prog Ser 342:177-190

Underwood AJ, Keough MJ (2001) Supply-side ecology: the nature and consequences of variations in recruitment of intertidal organisms. In: Bertness MD, Gaines SD, Hay ME

Editorial responsibility: William Peterson, Newport, Oregon, USA (ed) Marine community ecology. Sinauer, Sunderland, MA, p 183-200

Victor BC (1983) Recruitment and population dynamics of a coral reef fish. Science 219:419-420

Whitlock MC (2005) Combining probability from independent tests: the weighted Z-method is superior to Fisher's approach. J Evol Biol 18:1368-1373

Wing SR, Botsford L, Largier JL, Morgan LE (1995) Spatial variability in settlement of benthic invertebrates in a northern California upwelling system. Mar Ecol Prog Ser 128:199-211

Wing SR, Botsford L, Ralston JSV, Largier JL (1998) Meroplanktonic distribution and circulation in a coastal retention zone of the northern California upwelling system. Limnol Oceanogr 43:1710-1721

> Wing SR, Botsford L, Morgan LE, Diehl JM, Lundquist CJ (2003) Inter-annual variability in larval supply to populations of 3 invertebrate taxa in the northern California Current. Estuar Coast Shelf Sci 57:859-872

Yoshioka PM (1982) Role of planktonic and benthic factors in the population dynamics of the bryozoan, Membranipora membranacea. Ecology 63:457-468

Submitted: February 17, 2009; Accepted: July 10, 2009

Proofs received from author(s): October 26, 2009 